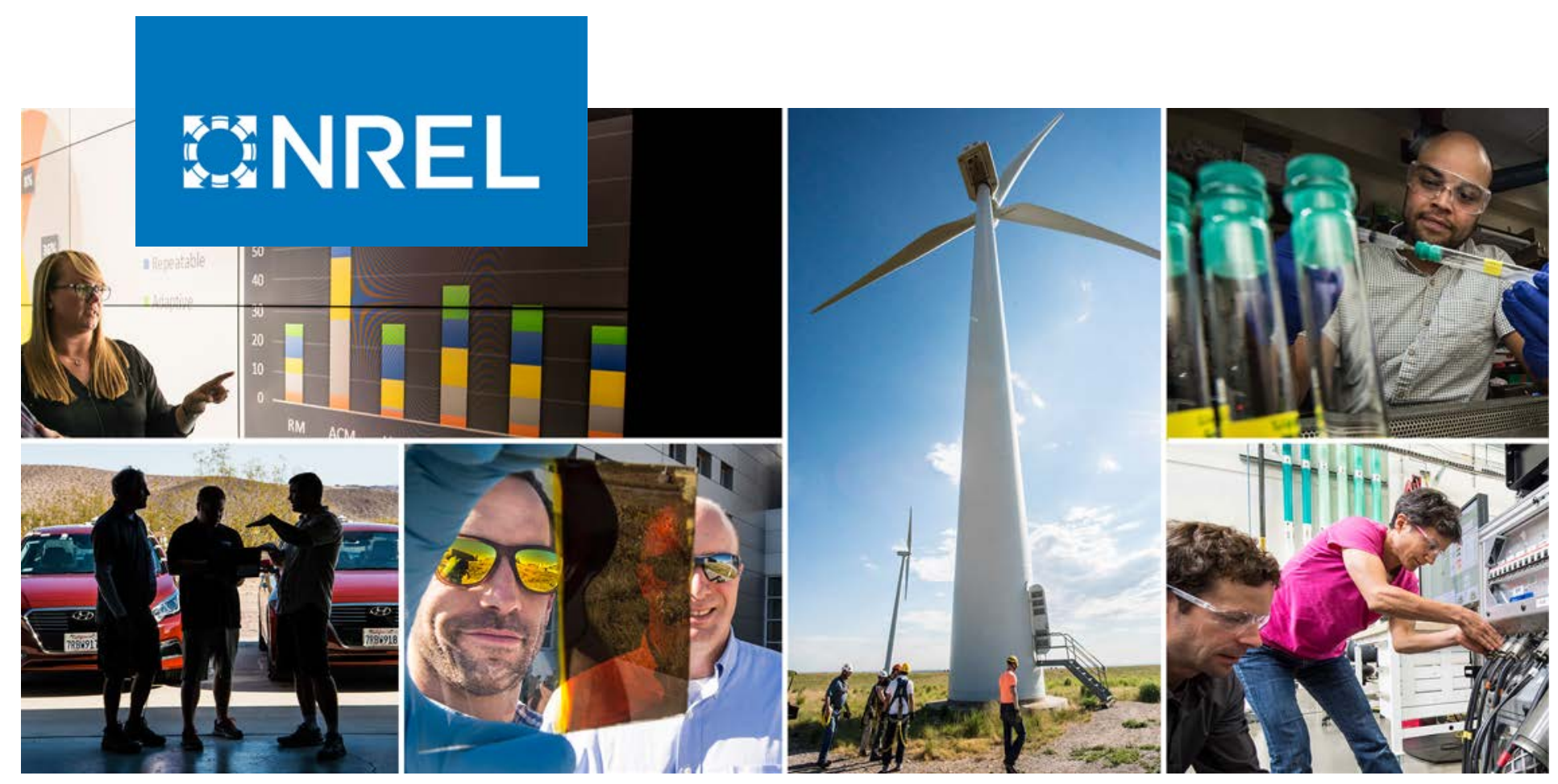

\title{
NREL Pyrheliometer Comparisons: September 23-October 4, 2019 (NPC-2019)
}

Ibrahim Reda, Afshin Andreas, Aron Habte, Peter Gotseff, Mark Kutchenreiter, and Martina Stoddard

National Renewable Energy Laboratory

NREL is a national laboratory of the U.S. Department of Energy Office of Energy Efficiency \& Renewable Energy

Operated by the Alliance for Sustainable Energy, LLC

This report is available at no cost from the National Renewable Energy Laboratory (NREL) at www.nrel.gov/publications.
Technical Report

NREL/TP-1900-75123

Revised December 2020 


\title{
BNREL
}

\section{NREL Pyrheliometer Comparisons: September 23-October 4, 2019 (NPC-2019)}

\author{
Ibrahim Reda, Afshin Andreas, Aron Habte, Peter Gotseff, \\ Mark Kutchenreiter, and Martina Stoddard
}

National Renewable Energy Laboratory

\author{
Suggested Citation \\ Reda, Ibrahim, Afshin Andreas, Aron Habte, Peter Gotseff, Mark Kutchenreiter, and \\ Martina Stoddard. 2019. NREL Pyrheliometer Comparisons: September 23-October 4, \\ 2019 (NPC-2019). Golden, CO: National Renewable Energy Laboratory. \\ NREL/TP-1900-75123. https://www.nrel.gov/docs/fy20osti/75123.pdf.
}

NREL is a national laboratory of the U.S. Department of Energy Office of Energy Efficiency \& Renewable Energy Operated by the Alliance for Sustainable Energy, LLC

This report is available at no cost from the National Renewable Energy Laboratory (NREL) at www.nrel.gov/publications.

Contract No. DE-AC36-08GO28308
Technical Report NREL/TP-1900-75123

Revised December 2020

National Renewable Energy Laboratory 15013 Denver West Parkway Golden, CO 80401 303-275-3000 • www.nrel.gov 


\section{NOTICE}

This work was authored by the National Renewable Energy Laboratory, operated by Alliance for Sustainable Energy, LLC, for the U.S. Department of Energy (DOE) under Contract No. DE-AC36-08GO28308. Funding provided by U.S. Department of Energy Office of Energy Efficiency and Renewable Energy Solar Energy Technologies Office. The views expressed herein do not necessarily represent the views of the DOE or the U.S. Government.

This report is available at no cost from the National Renewable Energy Laboratory (NREL) at www.nrel.gov/publications.

U.S. Department of Energy (DOE) reports produced after 1991 and a growing number of pre-1991 documents are available free via www.OSTI.gov.

Cover Photos by Dennis Schroeder: (clockwise, left to right) NREL 51934, NREL 45897, NREL 42160, NREL 45891, NREL 48097, NREL 46526.

NREL prints on paper that contains recycled content. 


\section{Errata}

This report, originally published in October 2019, has been revised in December 2020 to update the uncertainty values in Tables 2 and 3 . 


\section{Acknowledgments}

We sincerely appreciate the support of Solar Radiance Research Laboratory (SRRL) staff and National Renewable Energy Laboratory (NREL) management, the U.S. Department of Energy (DOE) Office of Energy Efficiency and Renewable Energy Solar Energy Technologies Program, the DOE Environmental Research/Atmospheric Radiation Measurement Program, and NREL's Environment, Safety, Health, \& Quality center. Our thanks also go to all the participants for their patience and cooperation during NREL Pyrheliometer Comparisons 2019, a weather-dependent exercise.

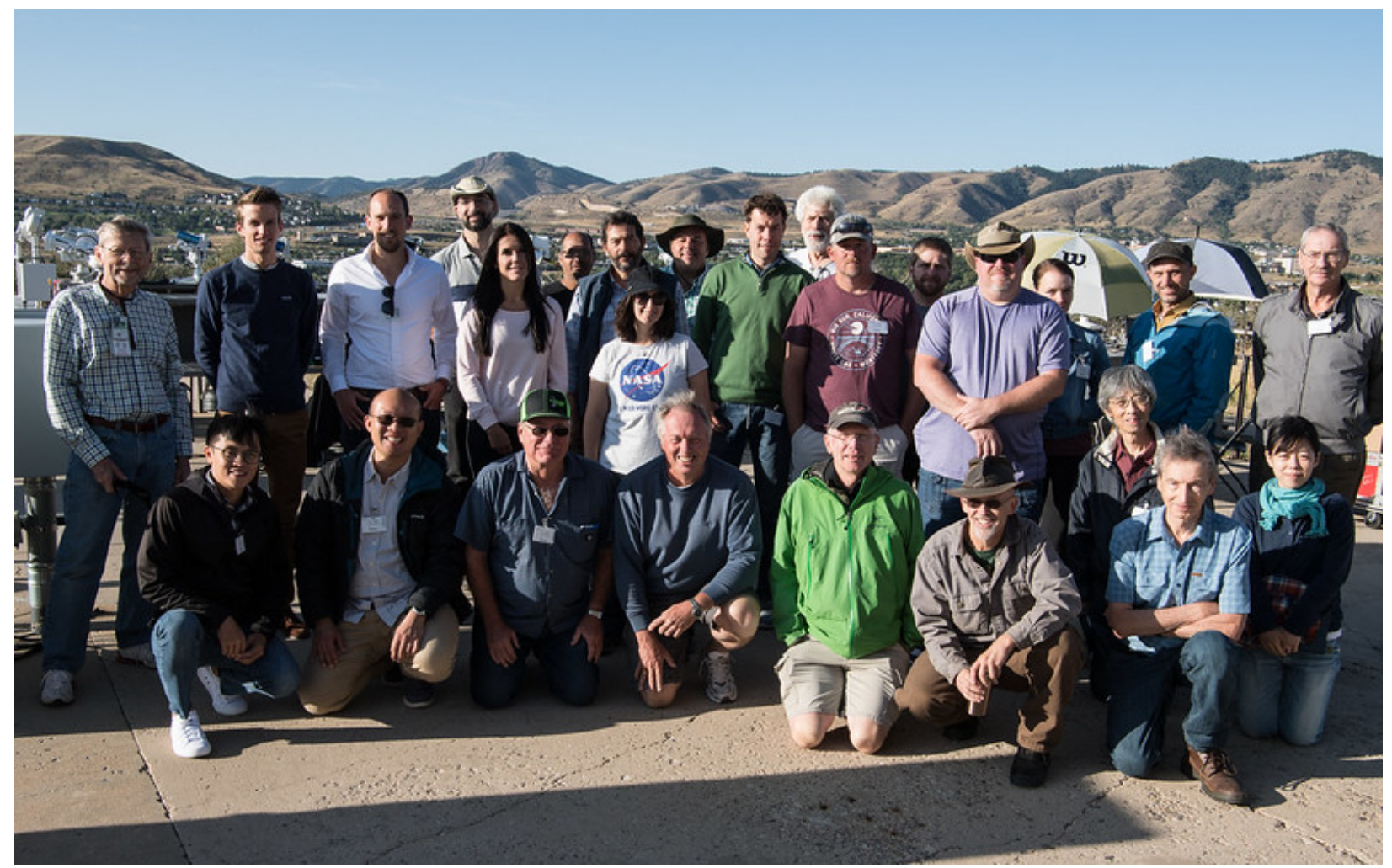

NPC-2019 participants, by Dennis Schroeder 


\section{List of Acronyms and Abbreviations}

$\begin{array}{ll}\text { AEMET } & \text { State Meteorological Agency (Spain) } \\ \text { AHF } & \text { Automatic Hickey-Frieden } \\ \text { BMS } & \text { Baseline Measurement System } \\ \text { BORCAL } & \text { Broadband Outdoor Radiometer Calibration } \\ \text { DOE } & \text { U.S. Department of Energy } \\ \text { IPC } & \text { International Pyrheliometer Comparison } \\ \text { IPC-XII } & \text { Twelfth International Pyrheliometer Comparisons } \\ \text { ISO } & \text { International Organization for Standardization } \\ \text { MST } & \text { Mountain Standard Time } \\ \text { NOAA/ESRL/GMD } & \text { National Oceanic and Atmospheric Administration's Earth System } \\ & \text { Research Laboratory, Global Monitoring Division } \\ \text { NPC } & \text { National Renewable Energy Laboratory Pyrheliometer Comparisons } \\ \text { NREL } & \text { National Renewable Energy Laboratory } \\ \text { PMOD/WRC } & \text { Physikalisch-Meteorologisches Observatorium Davos-World } \\ & \text { Radiation Center } \\ \text { SDp } & \text { pooled standard deviation } \\ \text { SI } & \text { International System of Units } \\ \text { SRRL } & \text { Solar Radiation Research Laboratory } \\ \text { TSG } & \text { Transfer Standard Group } \\ \text { WMO } & \text { World Meteorological Organization } \\ \text { WRR } & \text { World Radiometric Reference } \\ \text { WRR-TF } & \text { World Radiometric Reference transfer factor } \\ \text { WSG } & \text { World Standard Group } \\ \text { \%uA } & \text { Percentage Type-A standard uncertainty } \\ \text { NRdg } & \text { number of readings } \\ \text { uC } & \text { combined standard uncertainty } \\ \text { Eff DF } & \text { effective degrees of freedom } \\ & \end{array}$




\section{Executive Summary}

Accurate measurements of direct normal (beam) solar irradiance from pyrheliometers ${ }^{1}$ are important for developing and deploying solar energy conversion systems, for improving our understanding of Earth's energy budget for climate change studies, and for other science and technology applications involving solar flux. Providing these measurements places many demands on the quality system used by the operator of commercially available radiometers. Maintaining accurate radiometer calibrations that are traceable to an international standard is the first step in producing research-quality solar irradiance measurements.

In 1977, the World Meteorological Organization (WMO) established the World Radiometric Reference (WRR) as the international standard for the measurement of direct normal solar irradiance (Fröhlich 1991). The WRR is an internationally recognized, detector-based measurement standard determined by the collective performance of six electrically selfcalibrated absolute cavity radiometers comprising the World Standard Group (WSG). Various countries, including the United States, ${ }^{2}$ have contributed these specialized radiometers to the Physikalisch-Meteorologisches Observatorium Davos-World Radiation Center (PMOD/WRC) to establish the WSG.

As with all measurement systems, Absolute Cavity Radiometers (ACR) are subject to performance changes over time. Therefore, PMOD/WRC in Davos, Switzerland, hosts an quinquennial International Pyrheliometer Comparison (IPC) event for transferring the WRR to participating radiometers by invitation. ${ }^{3}$ The National Renewable Energy Laboratory (NREL) has represented the U.S. Department of Energy (DOE) in each IPC since 1980. And NREL has developed and maintained a select group of absolute cavity radiometers with direct calibration traceability to the WRR, and it uses these reference instruments to calibrate pyrheliometers and pyranometers using the International Organization for Standardization (ISO) 17025-accredited Broadband Outdoor Radiometer Calibration (BORCAL) process (Reda et al. 2008).

To fill the gap between each IPC, NREL pyrheliometer comparisons (NPCs) are held annually at the Solar Radiation Research Laboratory (SRRL) in Golden, Colorado. Open to all ACR owners and operators, each NPC provides an opportunity to determine the unique WRR transfer factor (WRR-TF) for each participating pyrheliometer. By adjusting all subsequent pyrheliometer measurements by the appropriate WRR-TF, the solar irradiance data are traceable to the WRR.

NPC-2019 was held September 23 through October 4, 2019. Participants operated 31 ACRs to simultaneously measure clear-sky direct normal solar irradiance during this period. The Transfer Standard Group (TSG) of reference radiometers for NPC-2019 consisted of four NREL radiometers with direct traceability to the WRR, each having participated in the Twelfth International Pyrheliometer Comparisons (IPC-XII) in the fall of 2015. As a result of NPC-2019, each participating absolute cavity radiometer was assigned a new WRR-TF, which is computed as the reference irradiance determined by the TSG divided by the observed irradiance from the participating radiometer. The performance of the TSG during NPC-2019 was consistent with previous comparisons, including IPC-XII. The measurement performance of the TSG allowed

\footnotetext{
${ }^{1}$ Pyrheliometers are a type of radiometer used to measure solar irradiance (i.e., radiant flux in Watts per square meter) on a surface normal to the apparent solar disk within a $5.0^{\circ}$ or $5.7^{\circ}$ field of view, depending on the optical design of the instrument. A solar tracker is used to maintain proper alignment of the pyrheliometer with the sun during daylight periods.

${ }^{2}$ The WSG includes radiometers on permanent loan from the Eppley Laboratory, Inc., and NREL.

${ }^{3}$ Appendix A lists the NPC-2019 participants and the pyrheliometers compared.
} 
the transfer of the WRR to each participating radiometer with an estimated uncertainty of \pm $0.36 \%$ with respect to the International System of Units.

The comparison protocol is based on data collection periods called runs. Each measurement run consists of an electrical self-calibration requiring five minutes for the Automatic Hickey-Frieden (AHF) cavities, a series of 49 solar irradiance measurements at 30-second intervals, and a postcalibration. ore than 3,000 reference irradiance measurements during NPC-2019. The clear-sky daily maximum direct normal irradiance level was $1,005 \mathrm{Wm}^{-2}$.

Ancillary environmental conditions (e.g., broadband turbidity, ambient temperature, relative humidity, wind speed, precipitable water vapor, and spectral data) collected at SRRL during the comparison are presented in Appendix B to document the environmental test conditions.

NPCs are planned annually at the SRRL to ensure worldwide homogeneity of solar radiation measurements traceable to the WRR. 


\section{Table of Contents}

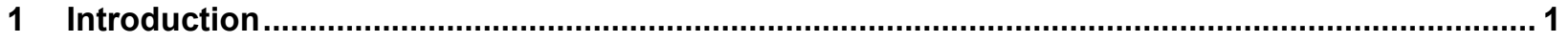

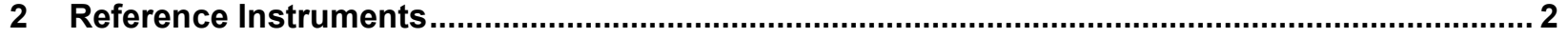

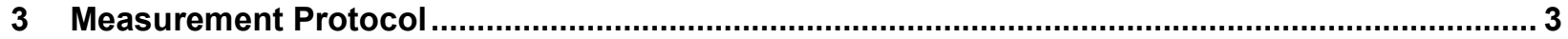

4 Transferring of the World Radiometric Reference ........................................................................ 4

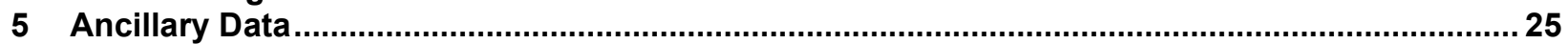

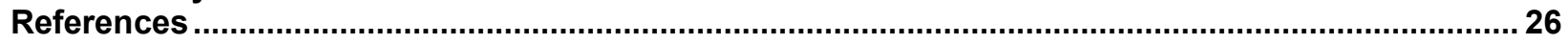

Appendix A. List of Participants and Pyrheliometers ............................................................. 27

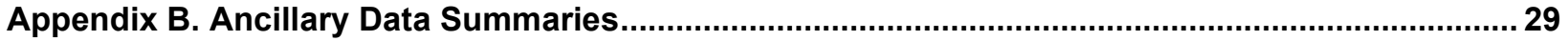




\section{List of Figures}

Figure 1. History of WRR reduction factors for NREL reference cavities ................................................. 5

Figure 2. WRR-Transfer Factor vs. Mountain Standard Time NPC-2019 for AHF 0000 ............................. 8

Figure 3. WRR-Transfer Factor vs. Mountain Standard Time NPC-2019 for AHF 14915 ........................... 9

Figure 4. WRR-Transfer Factor vs. Mountain Standard Time NPC-2019 for AHF23734 …....................... 9

Figure 5. WRR-Transfer Factor vs. Mountain Standard Time NPC-2019 for AHF28553 …....................... 10

Figure 6. WRR-Transfer Factor vs. Mountain Standard Time NPC-2019 for AHF 28560 ......................... 10

Figure 7. WRR-Transfer Factor vs. Mountain Standard Time NPC-2019 for AHF 29219-Window............. 11

Figure 8. WRR-Transfer Factor vs. Mountain Standard Time NPC-2019 for AHF 29222-Window ............ 11

Figure 9. WRR-Transfer Factor vs. Mountain Standard Time NPC-2019 for AHF 30110 .......................... 12

Figure 10. WRR-Transfer Factor vs. Mountain Standard Time NPC-2019 for AHF 30495-Window........... 12

Figure 11. WRR-Transfer Factor vs. Mountain Standard Time NPC-2019 for AHF 31041 ........................ 13

Figure 12. WRR-Transfer Factor vs. Mountain Standard Time NPC-2019 for AHF 31104-Window........... 13

Figure 13. WRR-Transfer Factor vs. Mountain Standard Time NPC-2019 for AHF 31105 ......................... 14

Figure 14. WRR-Transfer Factor vs. Mountain Standard Time NPC-2019 for AHF 31108 ........................ 14

Figure 15. WRR-Transfer Factor vs. Mountain Standard Time NPC-2019 for AHF 31114AWX ............... 15

Figure 16. WRR-Transfer Factor vs. Mountain Standard Time NPC-2019 for AHF 31116AWX-Window. 15

Figure 17. WRR-Transfer Factor vs. Mountain Standard Time NPC-2019 for AHF 31116AWX-Window. 16

Figure 18. WRR-Transfer Factor vs. Mountain Standard Time NPC-2019 for AHF 32452AWX-Window. 16

Figure 19. WRR-Transfer Factor vs. Mountain Standard Time NPC-2019 for AHF 32455 ........................ 17

Figure 20. WRR-Transfer Factor vs. Mountain Standard Time NPC-2019 for AHF 34926AWX ................ 17

Figure 21. WRR-Transfer Factor vs. Mountain Standard Time NPC-2019 for AHF 37816 ........................ 18

Figure 22. WRR-Transfer Factor vs. Mountain Standard Time NPC-2019 for PMO6 0401 ....................... 18

Figure 23. WRR-Transfer Factor vs. Mountain Standard Time NPC-2019 for PMO6 0816 ........................ 19

Figure 24. WRR-Transfer Factor vs. Mountain Standard Time NPC-2019 for PMO6 1601 ........................ 19

Figure 25. WRR-Transfer Factor vs. Mountain Standard Time NPC-2019 for PMO6 81109 ......................20

Figure 26. WRR-Transfer Factor vs. Mountain Standard Time NPC-2019 for PMO6 911204 ....................20

Figure 27. WRR-Transfer Factor vs. Mountain Standard Time NPC-2019 for PMO6cc 0103 ......................21

Figure 28. WRR-Transfer Factor vs. Mountain Standard Time NPC-2019 for PMO6cc 0803 …..................2 21

Figure 29. WRR-Transfer Factor vs. Mountain Standard Time NPC-2019 for PMO6-cc 105 ......................22

Figure 30. WRR-Transfer Factor vs. Mountain Standard Time NPC-2019 for PMO6cc 404 ........................22

Figure 31. WRR-Transfer Factor vs. Mountain Standard Time NPC-2019 for PMOD6 0806 ......................23

Figure 32. WRR-Transfer Factor vs. Mountain Standard Time NPC-2019 for TMI 67603 ..........................23

Figure 33. WRR-Transfer Factor vs. Mountain Standard Time NPC-2019 for TMI 68835 ..........................24

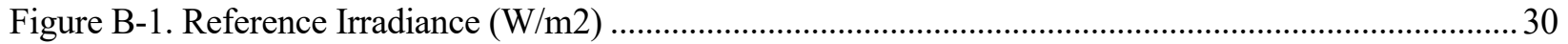

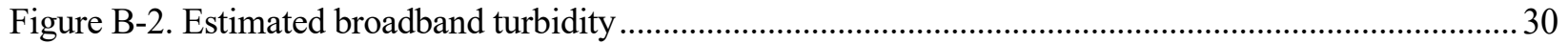

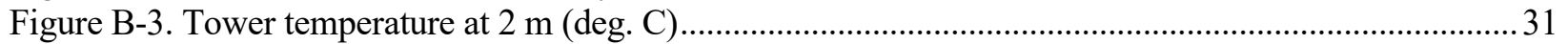

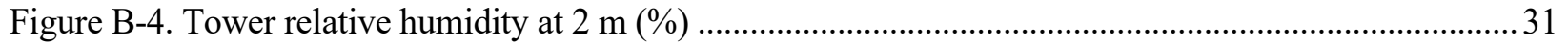

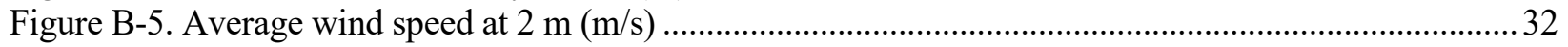

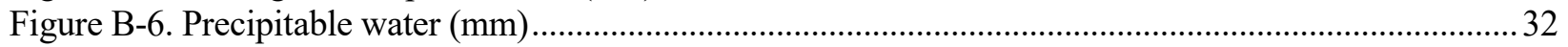

Figure B-7. 30-minute spectral irradiances for September 21, 2019 .......................................................... 33

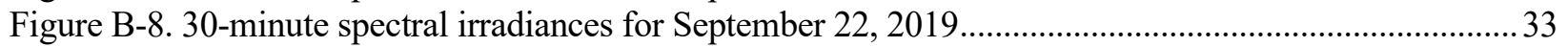

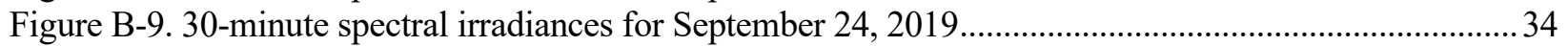

Figure B-10. 30-minute spectral irradiances for September 27, 2019 .................................................... 34

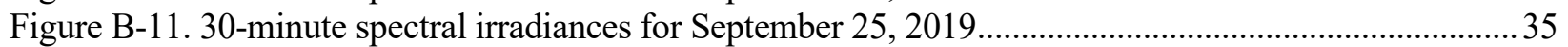

Figure B-12. 30-Minute Spectral Irradiances for September 27, 2019 ...................................................... 35

\section{List of Tables}

Table 1. Summary of IPC-XII Results for the NPC-2019 TSG ......................................................... 2

Table 2. Summary of Results for Proficiency Test During NPC-2019 ............................................... 6

Table 3. Summary of Results for Radiometers Participating in NPC-2019............................................ 7 


\section{Introduction}

Accurate measurements of broadband solar irradiance require radiometers with proper design and performance characteristics, correct installation, and documented operation and maintenance procedures, including regular calibration. Calibrations of any measuring device must be traceable to a recognized reference standard. The World Radiometric Reference (WRR) is the internationally recognized measurement standard for direct normal irradiance measurements of broadband solar radiation (Fröhlich 1991).

The WRR was established by the World Meteorological Organization (WMO) in 1977 and has been maintained by the Physikalisch-Meteorologisches Observatorium Davos-World Radiation Center (PMOD/WRC) ${ }^{4}$ in Switzerland. The WRR is maintained for broadband solar irradiance with an absolute uncertainty of better than $\pm 0.3 \%$ with respect to the International System of Units (SI) (Romero et al. 1996). The WRR standard is widely used to calibrate pyrheliometers and pyranometers with a wavelength response range that is compatible with the solar spectrum wavelengths of 280-3,000 nm.

Every five years, the WRR is transferred to WMO regional centers and other participants at the International Pyrheliometer Comparisons (IPC) event, which is held at the PMOD/WRC. The Twelfth IPC (IPC-XII) was completed in 2015 (Finsterle 2019). At each IPC, instantaneous measurements from the World Standard Group (WSG) are compared at 90-second intervals with the data from participating radiometers recorded under clear-sky conditions. A new WRR transfer factor (WRR-TF) is calculated for each participating radiometer based on the mean WRR of the WSG radiometers for each IPC. Multiplying the irradiance reading of each radiometer by its assigned WRR-TF will result in measurements that are traceable to SI units through the WRR and are therefore consistent with the international reference of solar radiation measurement.

In compliance with International Organization for Standardization (ISO) 17025 accreditation requirements for demonstrating interlaboratory proficiency, the National Renewable Energy Laboratory (NREL) hosts annual pyrheliometer comparisons at the Solar Radiation Research Laboratory (SRRL) in Golden, Colorado, for non-IPC years. The NREL Pyrheliometer Comparisons in 2019 (NPC-2019) was September 3 through October 4, 2019, at the SRRL. Participants operated absolute cavity radiometers during the comparisons. See Appendix A for a list of participants and affiliations.

The results presented in this report are based on clear-sky, direct normal solar irradiance data collected during NPC-2109. See Appendix B for the environmental conditions during NPC-2019.

\footnotetext{
${ }^{4}$ https://www.pmodwrc.ch
} 


\section{Reference Instruments}

NREL developed the transfer standard group (TSG) of four Absolute Cavity Radiometers (ACR) to serve as the transfer reference for each NPC. The radiometers comprising the TSG were included in the most recent IPC and maintain the WRR for NREL (see Table 1). Using the method described by Reda (1996), the mean of the TSG measurements was maintained for establishing the reference irradiance data for NPC-2019 data reduction. Table 1 lists the TSG absolute cavity radiometers with their WRR-TFs and pooled standard deviation $\left(\mathrm{SD}_{\mathrm{p}}\right)$ as determined from the latest IPC in 2015 (Finsterle 2016).

Table 1. Summary of IPC-XII Results for the NPC-2019 TSG

\begin{tabular}{|l|c|c|c|}
\hline Serial Number & $\begin{array}{l}\text { WRR Factor } \\
\text { (IPC-XII) }\end{array}$ & $\begin{array}{l}\text { Standard Deviation } \\
\text { (\%) }\end{array}$ & $\begin{array}{l}\text { Number of } \\
\text { Readings }\end{array}$ \\
\hline AHF 28968 & 0.99763 & 0.063 & 519 \\
\hline AHF 29220 & 0.99749 & 0.0621 & 523 \\
\hline AHF 30713 & 0.99723 & 0.0639 & 525 \\
\hline ATMI 68018 & 0.99660 & 0.0669 & 522 \\
\hline Mean WRR for the TSG & 0.99724 & SDp for the TSG: $0.06 \%$ \\
\hline
\end{tabular}

The pooled standard deviation, $\mathrm{SD}_{\mathrm{p}}$, for the TSG was computed from the following equation:

$$
S D_{p}=\sqrt{\frac{\sum_{i=1}^{m} n_{i} * S_{i}^{2}}{\sum_{i=1}^{m} n_{i}}}
$$

where:

- $\quad \mathrm{i}=\mathrm{i}^{\text {th }}$ cavity

- $\mathrm{m}=$ number of reference cavities

- $\mathrm{Si}=$ standard deviation of the $\mathrm{i}^{\text {th }}$ cavity, from IPC-XII

- $\mathrm{n}_{\mathrm{i}}=$ number of readings of the $\mathrm{i}^{\text {th }}$ cavity, from IPC-XII. 


\section{Measurement Protocol}

The decision to deploy instruments for a comparison was made daily during NPC-2019. Data were collected only during clear-sky conditions, which were determined visually and from the stability of pyrheliometer readings. Simultaneous direct normal solar irradiance measurements were taken by most cavity radiometers in groups of 49 observations at 30 -second intervals (PMO6 used 90-, 80-, or 30-second open/closed-shutter cycles).

Each group of observations is called a run. An electrical self-calibration of each Automatic Hickey-Frieden (AHF) ACR was performed before each run. Previous WRR-TFs determined from results of IPCs or NPCs were not applied to the observations. The original manufacturer's calibration factor was used according to the standard operating procedure provided by the manufacturer for each radiometer. A timekeeper announced the beginning of each calibration period and gave a five-minute countdown before the start of each run to facilitate the AHF cavity self-calibrations and the simultaneous start for each participant.

By consensus, at least 300 observations from each radiometer were required to determine the WRR-TF for an NPC. A statistically significant data set was required to derive the WRR-TF for each pyrheliometer. Data from each pyrheliometer/operator system were emailed at the end of the day. 


\section{Transferring of the World Radiometric Reference}

The primary purpose of an NPC is to transfer the current WRR from the NPC-TSG to each participating ACR. This requires that the participating pyrheliometers and the TSG collect simultaneous measurements of clear-sky direct normal (beam) solar irradiance. Calibration Requirements

Following WMO guidelines (Romero 1995), the following conditions were required before data collection was accomplished during NPC-2019:

- The radiation source was the sun, and irradiance levels were $>700 \mathrm{Wm}^{-2}$.

- A Digital Multimeter with an uncertainty $<0.05 \%$ or better was used to measure the thermopile signals from each radiometer.

- Solar trackers were aligned with a slope angle within $\pm 0.25^{\circ}$.

- Wind speed was low $(<5 \mathrm{~m} / \mathrm{s})$ from the direction of the solar azimuth $\pm 30^{\circ}$.

- Cloud cover was $<1 / 8$ of the sky dome, with an angular distance $>15^{\circ}$ from the sun.

\subsection{Determining the Reference Irradiance}

Four ACRs that are maintained by NREL and were part of IPC-XII were used as the TSG to transfer the WRR in the comparison. The WRR-TF for each TSG is presented in Table 1 (above). The reference irradiance at each reading was calculated using the following steps, as described by Reda (1996):

1. Each irradiance reading of the TSG is divided by the irradiance measured by AHF 28968 , for its participation in many IPCs.

2. By maintaining the mean of WRR for the TSG, a new WRR-TF for NPC-2019 is recalculated for each of the TSG cavities (see Figure 2).

3. The reference irradiance for each 30 -second observation in a run is computed as the mean of the simultaneous reference irradiances measured by the TSG. The reference irradiance reading for each cavity in the TSG is the irradiance reading of the cavity multiplied by its new WRR-TF calculated in Step 2.

\subsection{Data Analysis Criteria}

AHF 28968 was used to check irradiance stability at the time of each comparison reading during a run. Stable irradiance readings are defined to within $1.0 \mathrm{Wm}^{-2}$ during an interval of two seconds centered on each reading time (i.e., one second before and one second after the recorded reading). Unstable irradiance readings were marked in the data record and automatically rejected from the data analysis; historically, this has affected fewer than $10 \%$ of the data collected during an NPC. Also rejected were all calculated ratios of the test instrument irradiance divided by AHF 28968 irradiance that deviated from their mean by $0.3 \%$ (Reda 1996). Typically, data rejected from the analysis in this manner were the result of failed tracker alignment, problems with the precalibration, or a similar cause for bias greater than expected from a properly functioning absolute cavity radiometer.

\subsection{Measurements}

NPC-2019 was completed for most participants on October 3, after more than 3,000 data points were collected by the reference cavities during the requisite clear-sky conditions. The actual number of readings for each participating radiometer compared with the reference irradiance 
varied according to the data analysis selection criteria described above. Additionally, some instruments experienced minor data loss because various problems occurred with the measurement systems or operations.

\subsection{Results}

The historical results for the TSG are presented in Figure 1. To evaluate the performance of these instruments, the standard deviations of each radiometer were monitored during the comparisons. The results suggest successful performance of the TSG during this NPC.

For the TSG, the NPC-2019 WRR-TF did not change by more than a fraction of the standard deviation derived during IPC-XII in 2015 (see Figure 2.).

For NPC-2019 Proficiency Test, the results of the participating cavities in IPC-XII and NPC2019 were evaluated using the following equation:

$$
E_{n}=\frac{W R R_{I P C}-W R R_{N P C}}{\sqrt{U 95_{I P C}^{2}+U 95_{N P C}^{2}}}
$$

where $\mathrm{E}_{\mathrm{n}}$ must lie in the interval -1 to +1 .

From Table 2, $\mathrm{E}_{\mathrm{n}}$ for all cavities was well within the interval -1 to +1 (i.e., the WRR from NPC2019 is consistent with the WRR from IPC-XII).

\section{WRR-RF for NREL Reference Cavities}

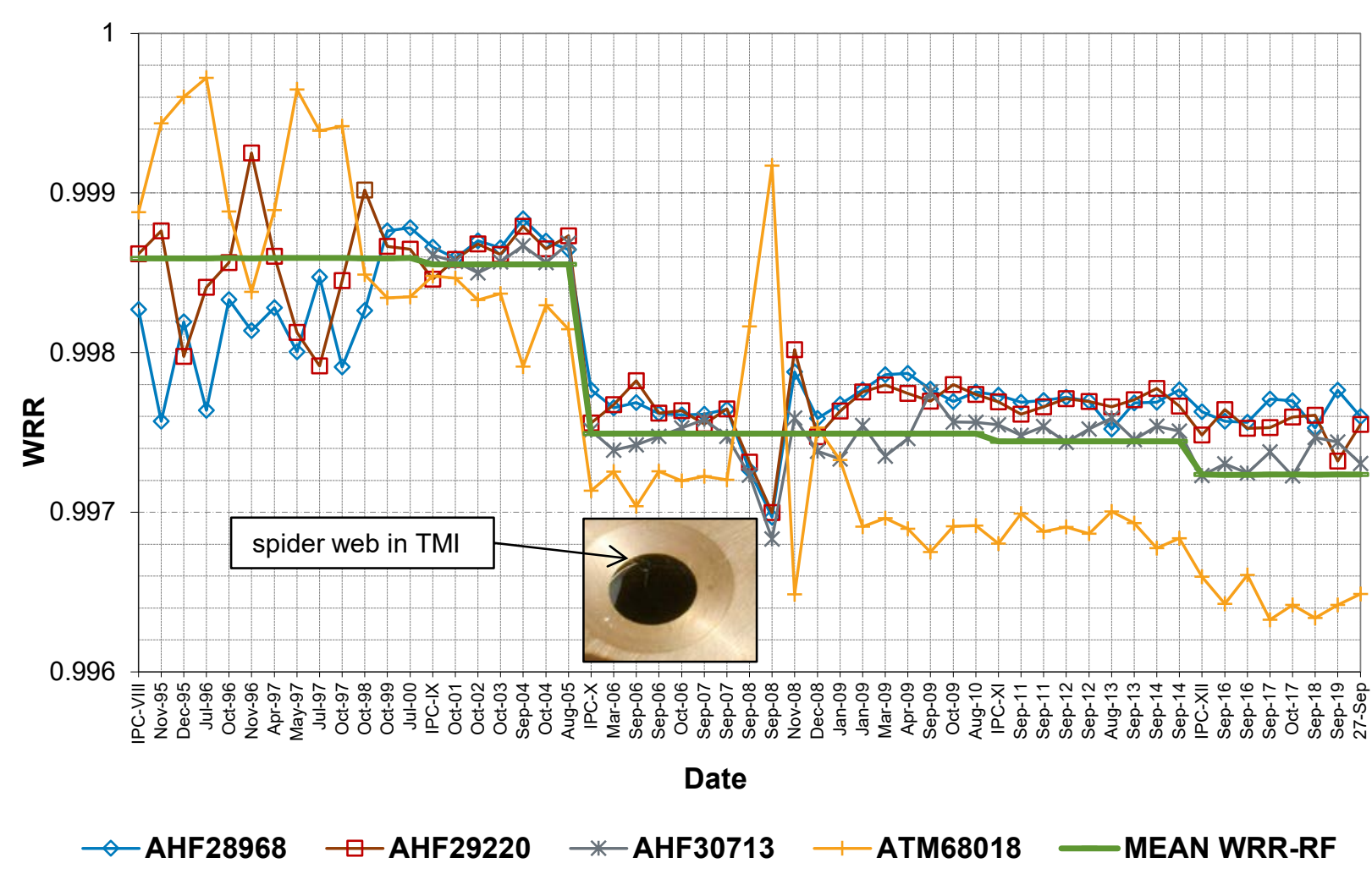

Figure 1. History of WRR reduction factors for NREL reference cavities 
Table 2. Summary of Results for Proficiency Test During NPC-2019

\begin{tabular}{|c|c|c|c|c|c|}
\hline $\begin{array}{c}\text { Participating } \\
\text { Cavity }\end{array}$ & IPC-XII & $\%$ U95 & NPC-2019 & $\%$ U95 & Red if $\operatorname{abs}($ En) $>1$ \\
\hline AHF 0000 & 1.000307 & 0.35 & 1.00271 & 0.38 & -0.46 \\
\hline AHF 14915 & 0.99954 & 0.35 & 0.99974 & 0.38 & -0.04 \\
\hline AHF 23734 & 0.99819 & 0.35 & 0.99818 & 0.37 & 0.00 \\
\hline AHF 28553 & 0.99774 & 0.35 & 0.99767 & 0.37 & 0.01 \\
\hline AHF 31041 & 0.99639 & 0.36 & 0.99660 & 0.38 & -0.04 \\
\hline AHF 31105 & 0.99866 & 0.36 & 0.99805 & 0.37 & 0.12 \\
\hline AHF 31114AWX & 1.00121 & 0.33 & 1.00141 & 0.37 & -0.04 \\
\hline AHF 32448AWX & 0.99999 & 0.35 & 1.00030 & 0.38 & -0.06 \\
\hline AHF 32455 & 1.00138 & 0.33 & 1.00061 & 0.38 & 0.15 \\
\hline AHF 37816 & 0.99959 & 0.33 & 0.99929 & 0.38 & 0.06 \\
\hline PMO6 0816 & 0.99984 & 0.45 & 1.00020 & 0.43 & -0.06 \\
\hline PMO6 81109 & 0.99832 & 0.32 & 0.99821 & 0.38 & 0.02 \\
\hline PMO6 911204 & 0.99945 & 0.41 & 1.00047 & 0.40 & -0.18 \\
\hline Pmo6cc 0103 & 0.99792 & 0.32 & 0.99786 & 0.39 & 0.01 \\
\hline PMO6cc 105 & 1.00141 & 0.35 & 1.00118 & 0.38 & 0.04 \\
\hline PMO6cc 0404 & 0.99821 & 0.31 & 0.99952 & 0.39 & -0.26 \\
\hline TMI 68835 & 1.000714 & 0.32 & 0.99984 & 0.40 & 0.17 \\
\hline
\end{tabular}


Table 3. Summary of Results for Radiometers Participating in NPC-2019

\begin{tabular}{|c|c|c|c|c|}
\hline $\mathbf{S} / \mathbf{N}$ & WRR (NPC-2019) & SD & NRDG & \%U95 \\
\hline AHF 0000 & 1.00271 & 0.0006 & 2781 & 0.38 \\
\hline AHF 14915 & 0.99974 & 0.0006 & 2723 & 0.38 \\
\hline AHF 23734 & 0.99818 & 0.0004 & 3164 & 0.37 \\
\hline AHF 28553 & 0.99767 & 0.0005 & 1915 & 0.37 \\
\hline AHF 28560 & 1.00251 & 0.0007 & 1824 & 0.38 \\
\hline AHF 29219-Window & 1.06179 & 0.0009 & 2828 & 0.40 \\
\hline AHF 29222-Window & 1.05756 & 0.0012 & 2896 & 0.43 \\
\hline AHF 30110 & 1.06766 & 0.0011 & 1021 & 0.42 \\
\hline AHF 30495-Window & 1.05797 & 0.0017 & 2852 & 0.48 \\
\hline AHF 31041 & 0.99660 & 0.0006 & 837 & 0.38 \\
\hline AHF 31105 & 0.99805 & 0.0003 & 494 & 0.37 \\
\hline AHF 31102 & 1.00052 & 0.0005 & 1775 & 0.37 \\
\hline AHF 31104-Window & 1.03836 & 0.0009 & 2347 & 0.40 \\
\hline AHF 31108 & 0.99742 & 0.0012 & 1948 & 0.43 \\
\hline AHF 31114AWX & 1.00141 & 0.0005 & 1869 & 0.37 \\
\hline AHF 31116AWX-Window & 1.06590 & 0.0009 & 1892 & 0.40 \\
\hline AHF 32448AWX & 1.00030 & 0.0006 & 1889 & 0.38 \\
\hline AHF 32452AWX-Window & 1.03166 & 0.0013 & 3164 & 0.44 \\
\hline AHF 32455 & 1.00061 & 0.0006 & 1835 & 0.38 \\
\hline AHF 34926AWX & 1.00028 & 0.0008 & 1861 & 0.40 \\
\hline AHF 37816 & 0.99929 & 0.0005 & 1821 & 0.38 \\
\hline PM06 1601 & 1.00317 & 0.0006 & 927 & 0.38 \\
\hline PMO6 0401 & 1.02136 & 0.0007 & 1826 & 0.38 \\
\hline PMO6 0816 & 1.00020 & 0.0012 & 936 & 0.43 \\
\hline PMO6 81109 & 0.99821 & 0.0006 & 962 & 0.38 \\
\hline PMO6 911204 & 1.00047 & 0.0008 & 1034 & 0.40 \\
\hline Pmo6cc 0103 & 0.99786 & 0.0007 & 703 & 0.39 \\
\hline PMO6-cc 0803 & 1.00019 & 0.0006 & 446 & 0.38 \\
\hline PMO6cc 105 & 1.00118 & 0.0006 & 397 & 0.38 \\
\hline PMO6cc 404 & 0.99952 & 0.0008 & 399 & 0.39 \\
\hline PMOD6 0807 & 1.00443 & 0.0009 & 662 & 0.40 \\
\hline TMI 67603 & 0.99987 & 0.0006 & 1937 & 0.38 \\
\hline TMI 68835 & 0.99984 & 0.0009 & 3033 & 0.40 \\
\hline
\end{tabular}


The uncertainty of the WRR-TF associated with each participating radiometer with respect to SI was calculated using the following equation:

$$
U_{95}= \pm 1.96 * \sqrt{u_{A}^{2}+u_{B}^{2}}
$$

where:

- $\quad \mathrm{U} 95=$ uncertainty of the WRR-TF (in percent) determined at NPC-2019 with $95 \%$ confidence level

- $\quad 1.96=$ coverage factor

- $\mathrm{uA}=$ Type A standard uncertainty $=$ standard deviation of each participating radiometer (in \%) determined at NPC-2019

- $\mathrm{uB}=$ Type $\mathrm{B}$ standard uncertainty

- $\mathrm{uB}= \pm \sqrt{\left(\frac{0.3}{\sqrt{3}}\right)^{2}+0.06^{2}}$

where:

○ 0.3 = Estimated expanded uncertainty of the WRR scale with respect to SI, in \%

○ $\sqrt{3}=$ Coverage factor for rectangular distribution

○ $0.06=$ Pooled standard deviation of the four reference radiometers (TSG) that participated in IPC-XII (September/October 2015), in \%.

The statistical analyses of WRR-TF for the participating pyrheliometers are presented in Figure 2 through Figure 33. These graphical summaries indicate the mean, standard deviation, and histograms of the WRR-TF determined during NPC-2019.

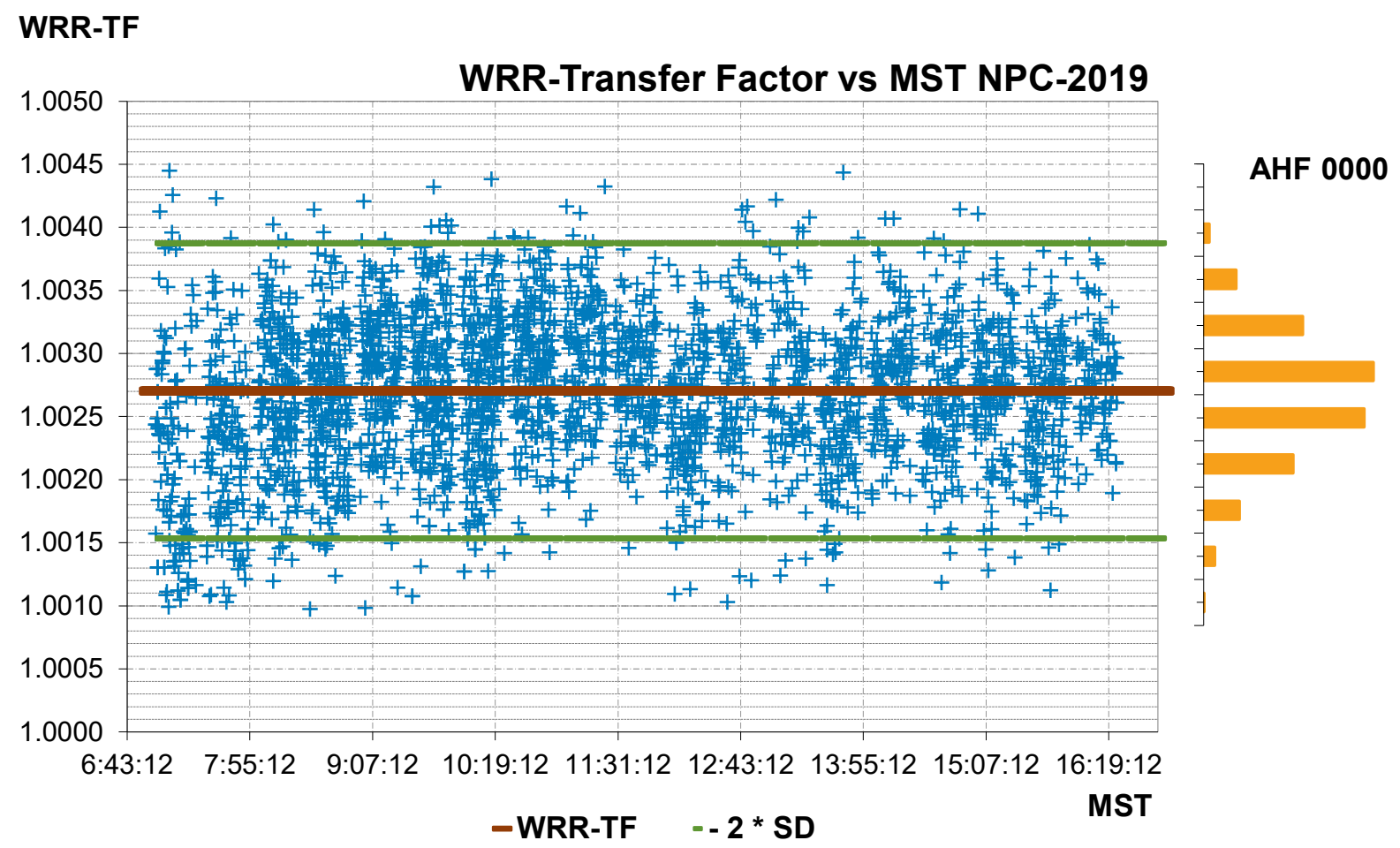

Figure 2. WRR-Transfer Factor vs. Mountain Standard Time NPC-2019 for AHF 0000 


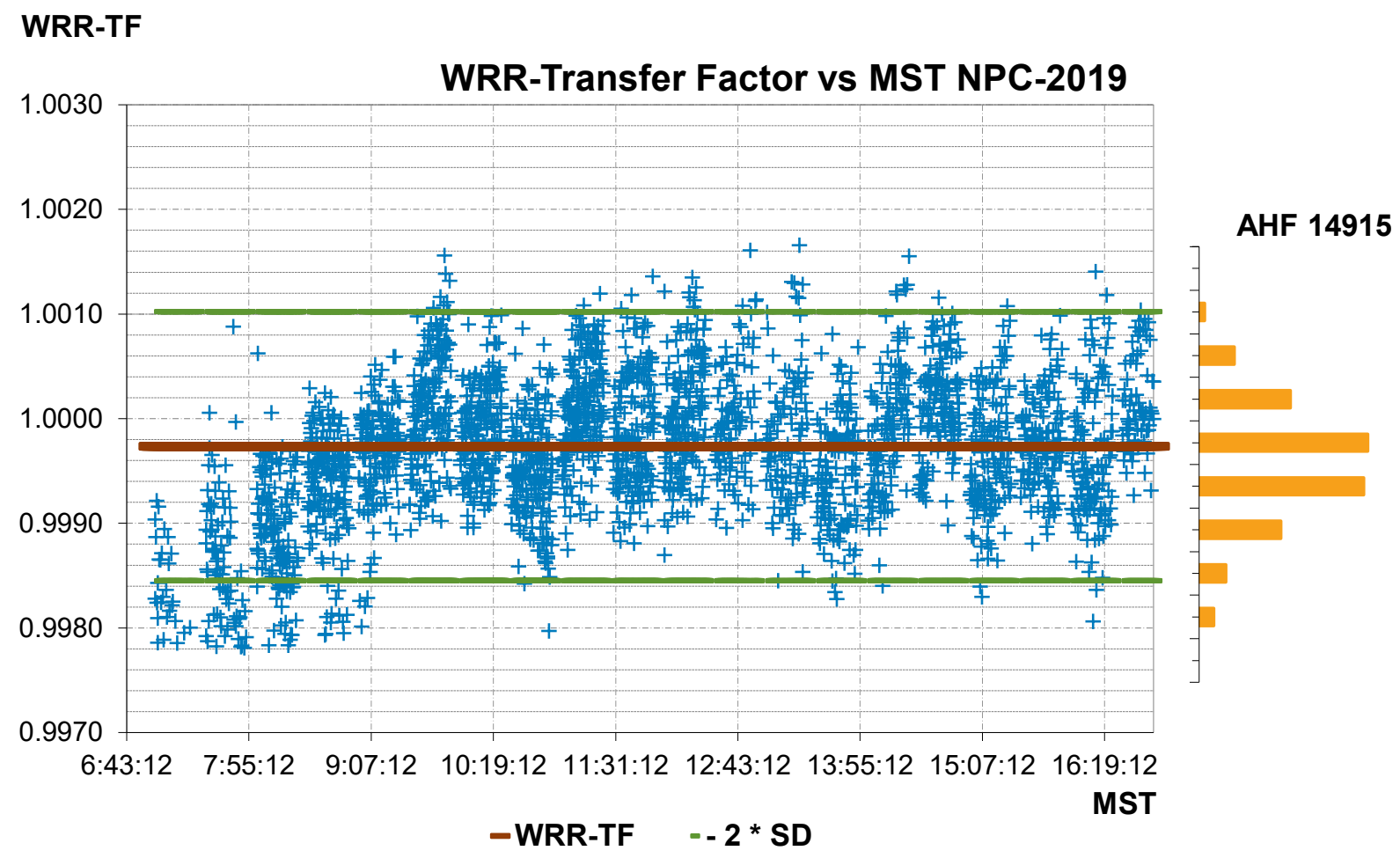

Figure 3. WRR-Transfer Factor vs. Mountain Standard Time NPC-2019 for AHF 14915

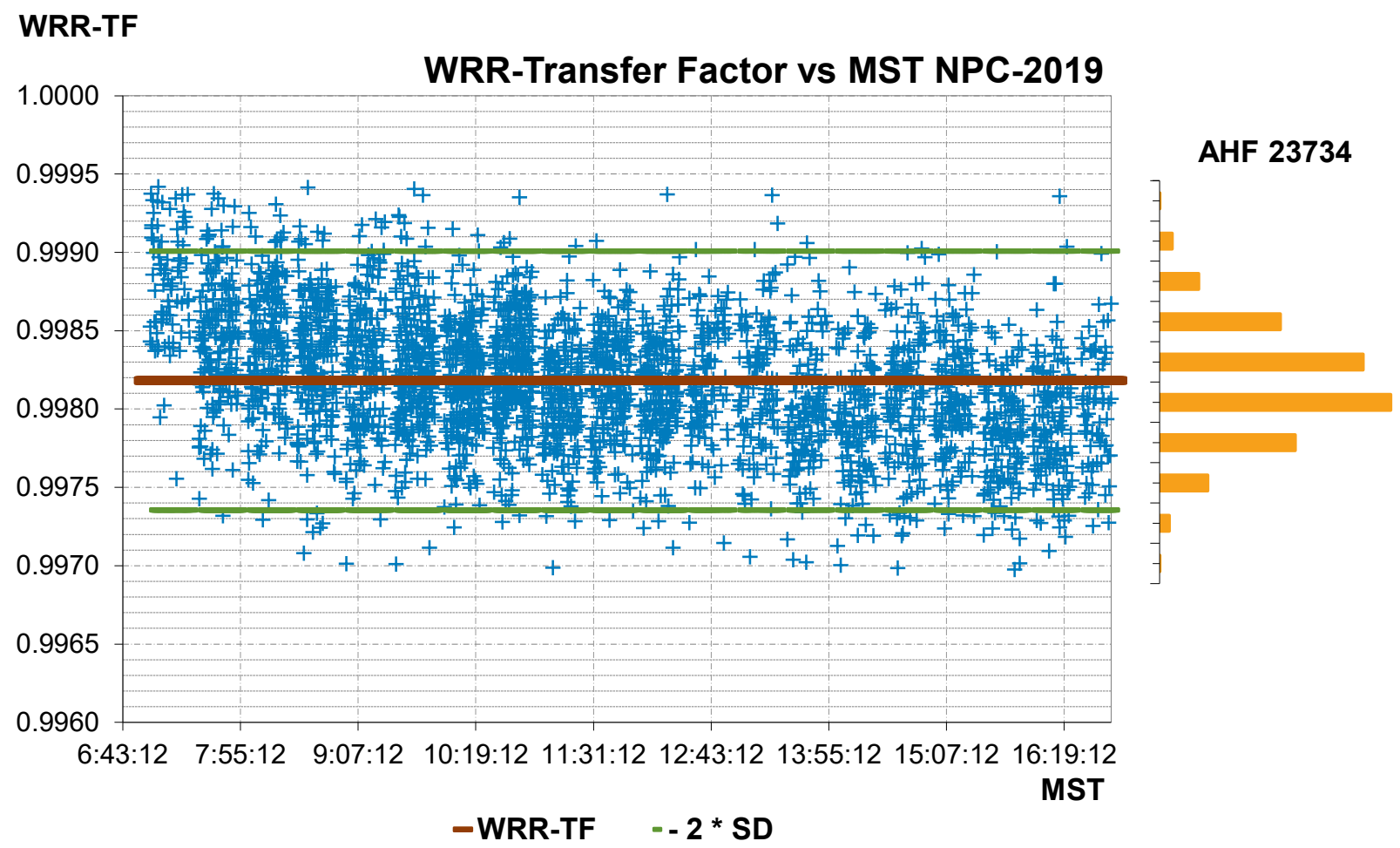

Figure 4. WRR-Transfer Factor vs. Mountain Standard Time NPC-2019 for AHF23734 


\section{WRR-TF}

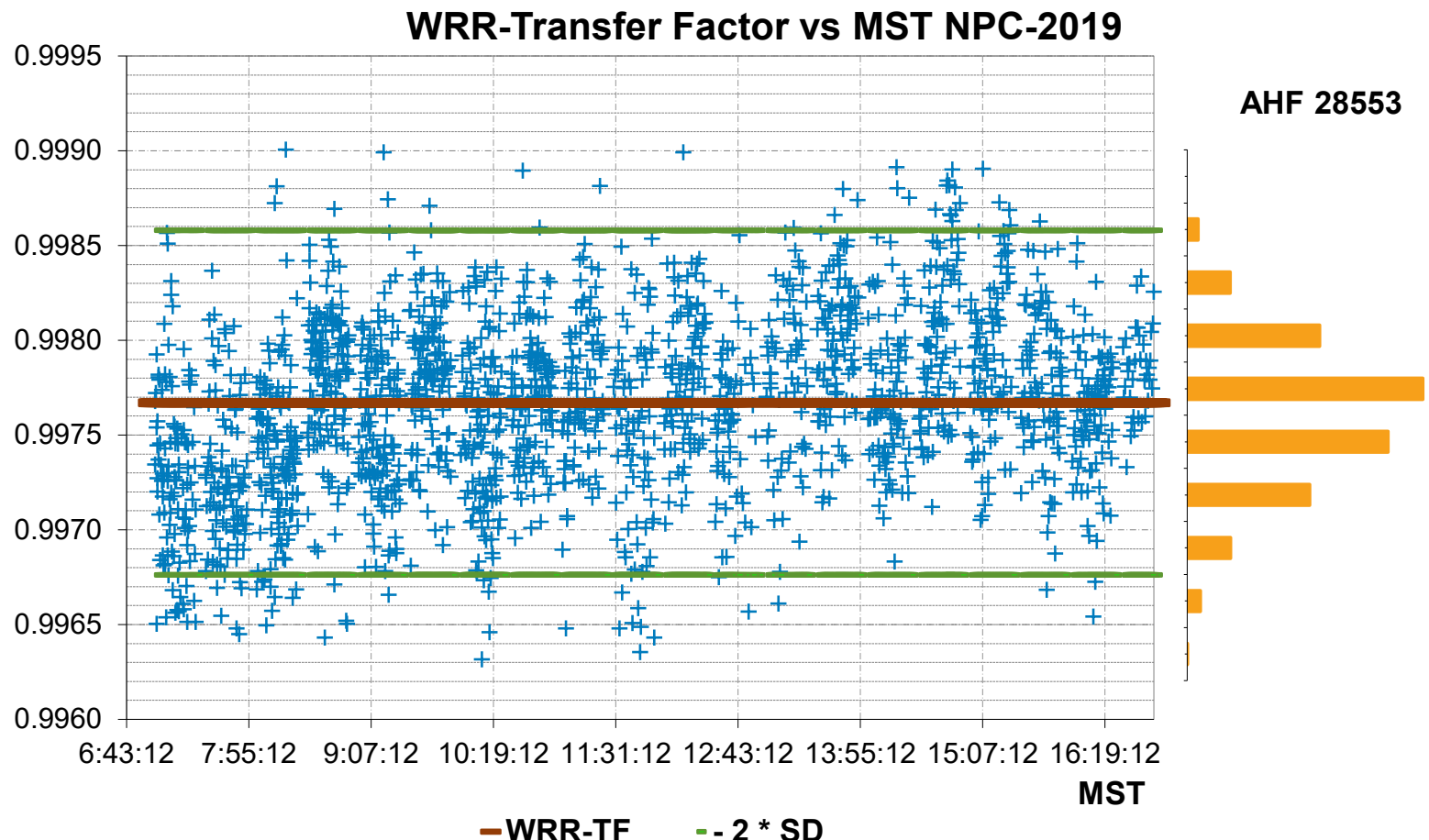

Figure 5. WRR-Transfer Factor vs. Mountain Standard Time NPC-2019 for AHF28553

\section{WRR-TF}

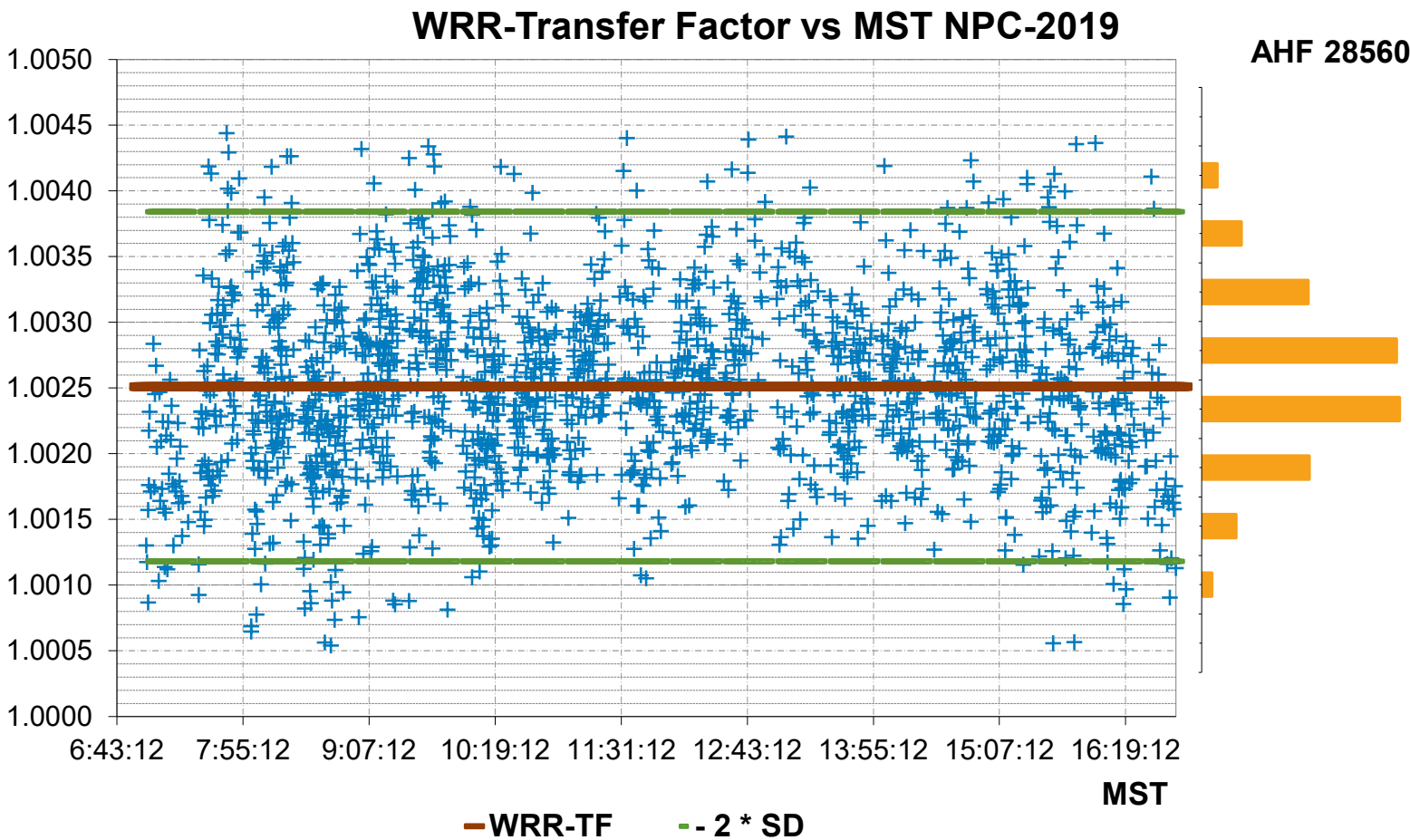

Figure 6. WRR-Transfer Factor vs. Mountain Standard Time NPC-2019 for AHF 28560 


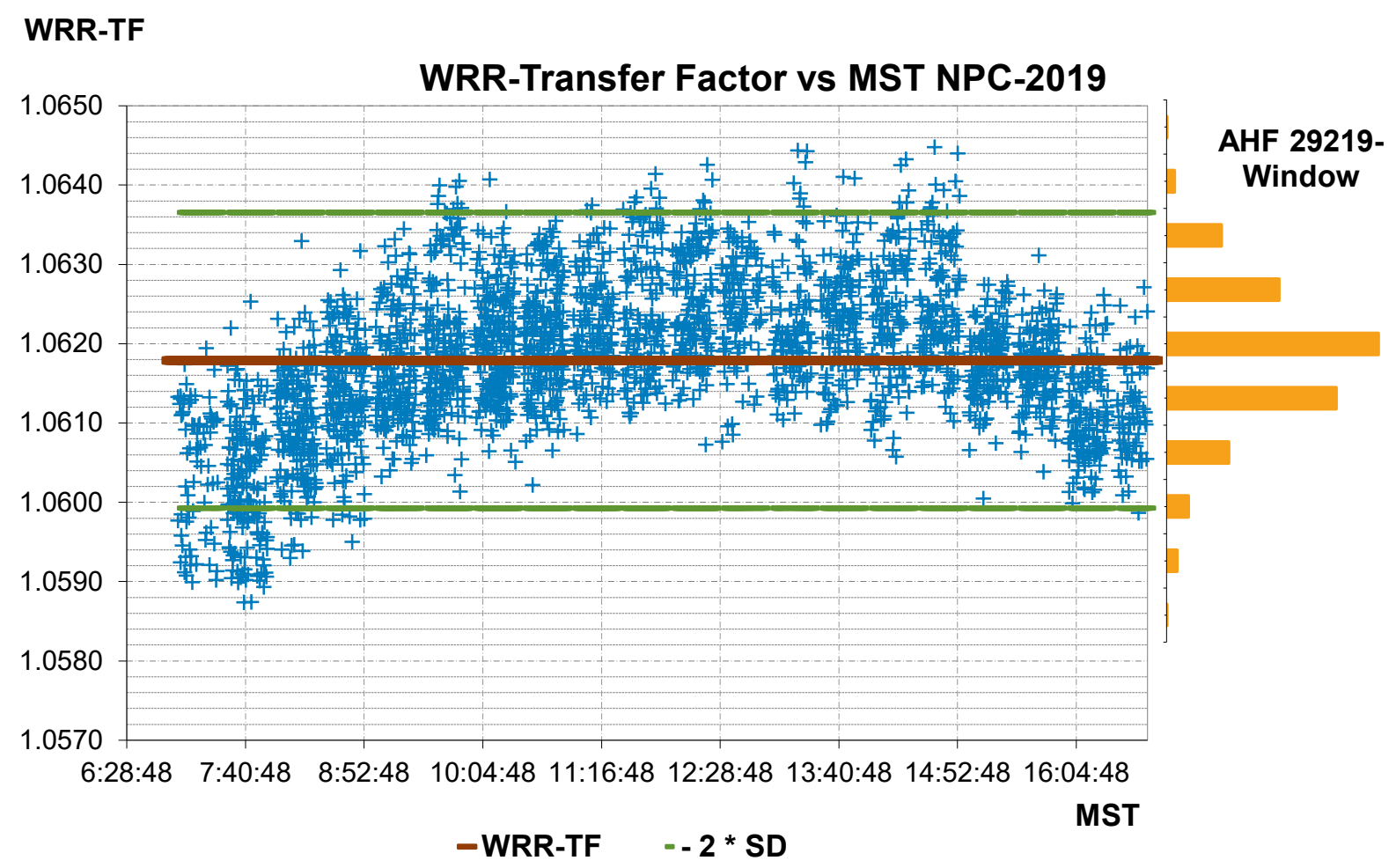

Figure 7. WRR-Transfer Factor vs. Mountain Standard Time NPC-2019 for AHF 29219-Window

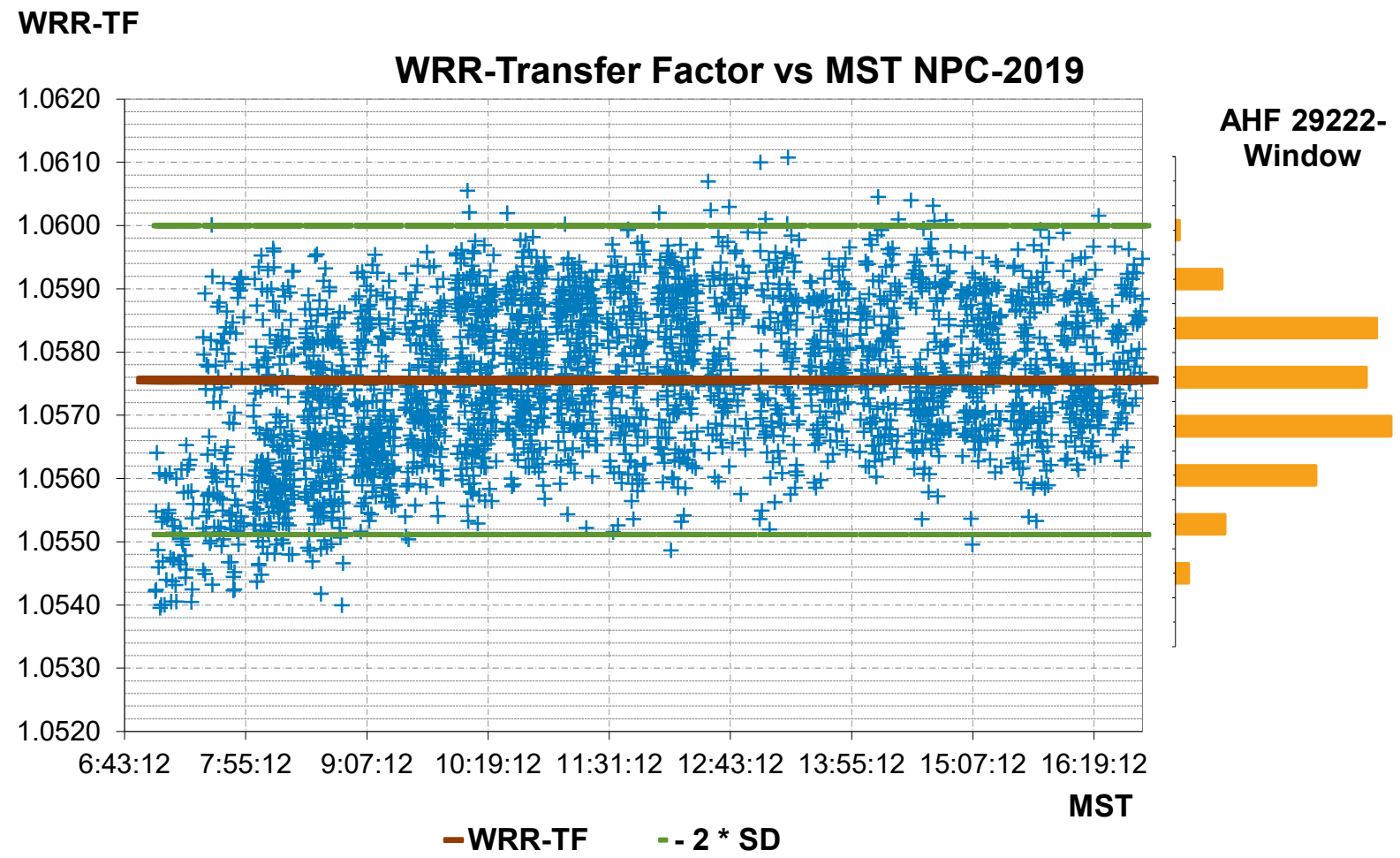

Figure 8. WRR-Transfer Factor vs. Mountain Standard Time NPC-2019 for AHF 29222-Window 


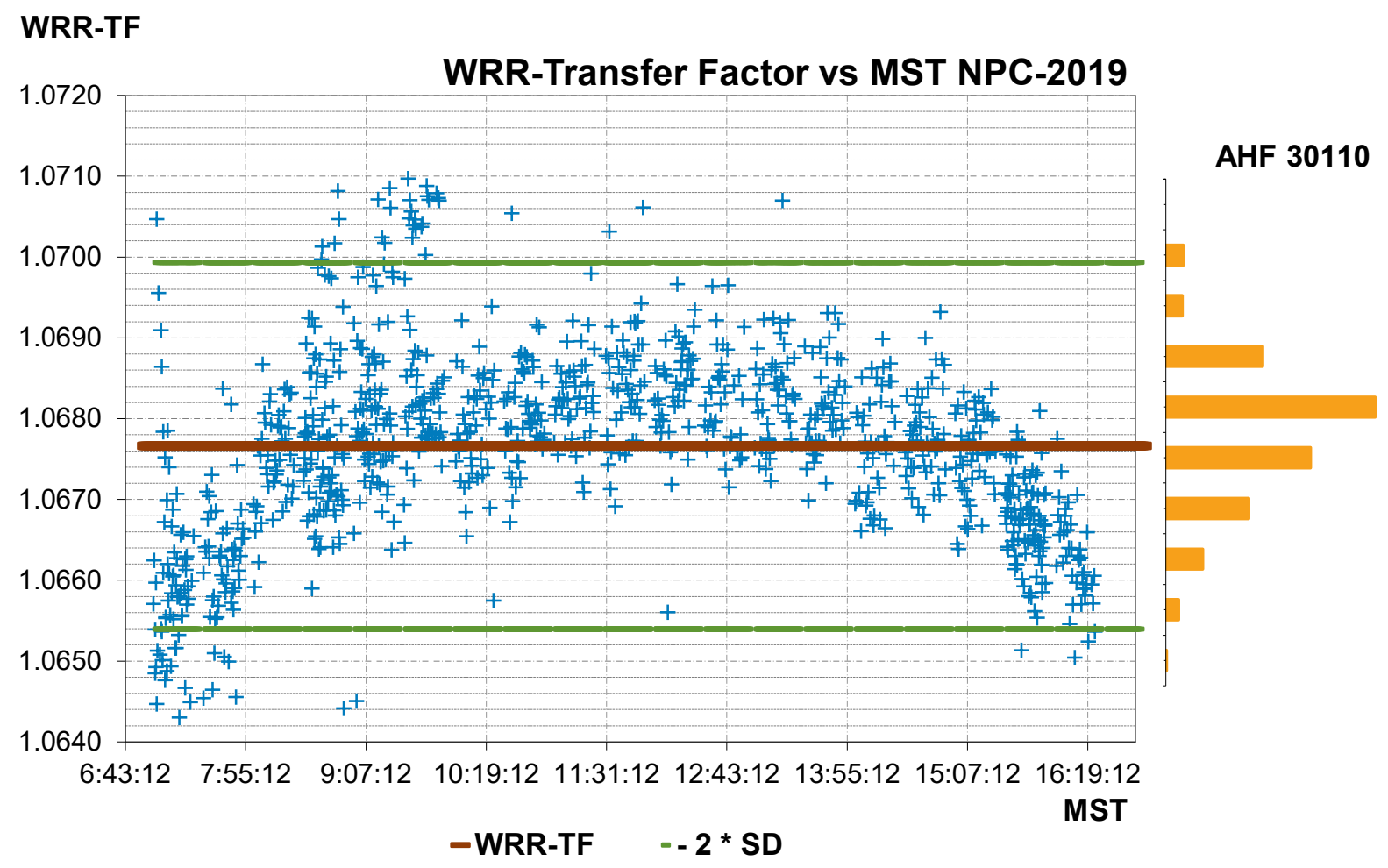

Figure 9. WRR-Transfer Factor vs. Mountain Standard Time NPC-2019 for AHF 30110

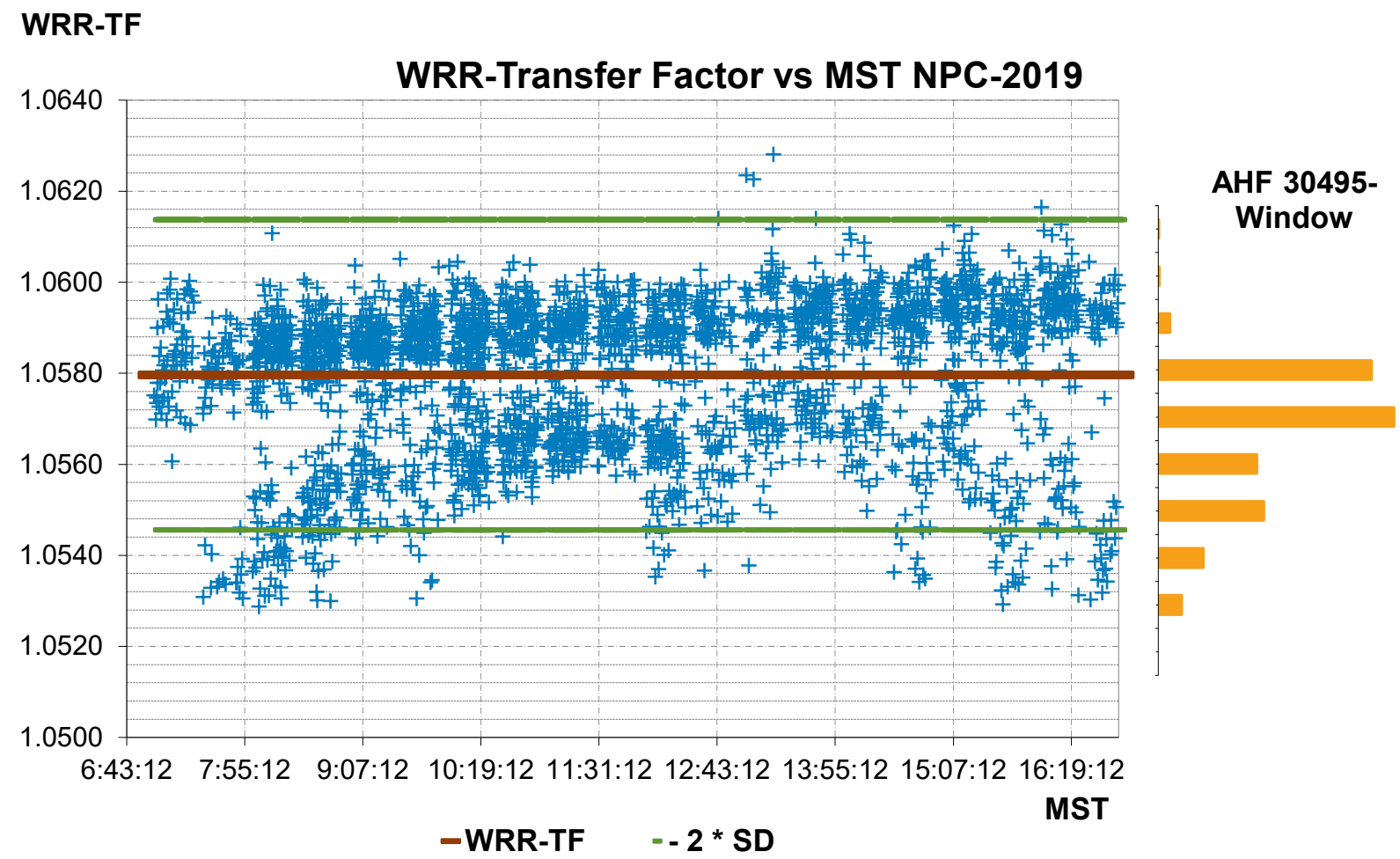

Figure 10. WRR-Transfer Factor vs. Mountain Standard Time NPC-2019 for AHF 30495-Window 


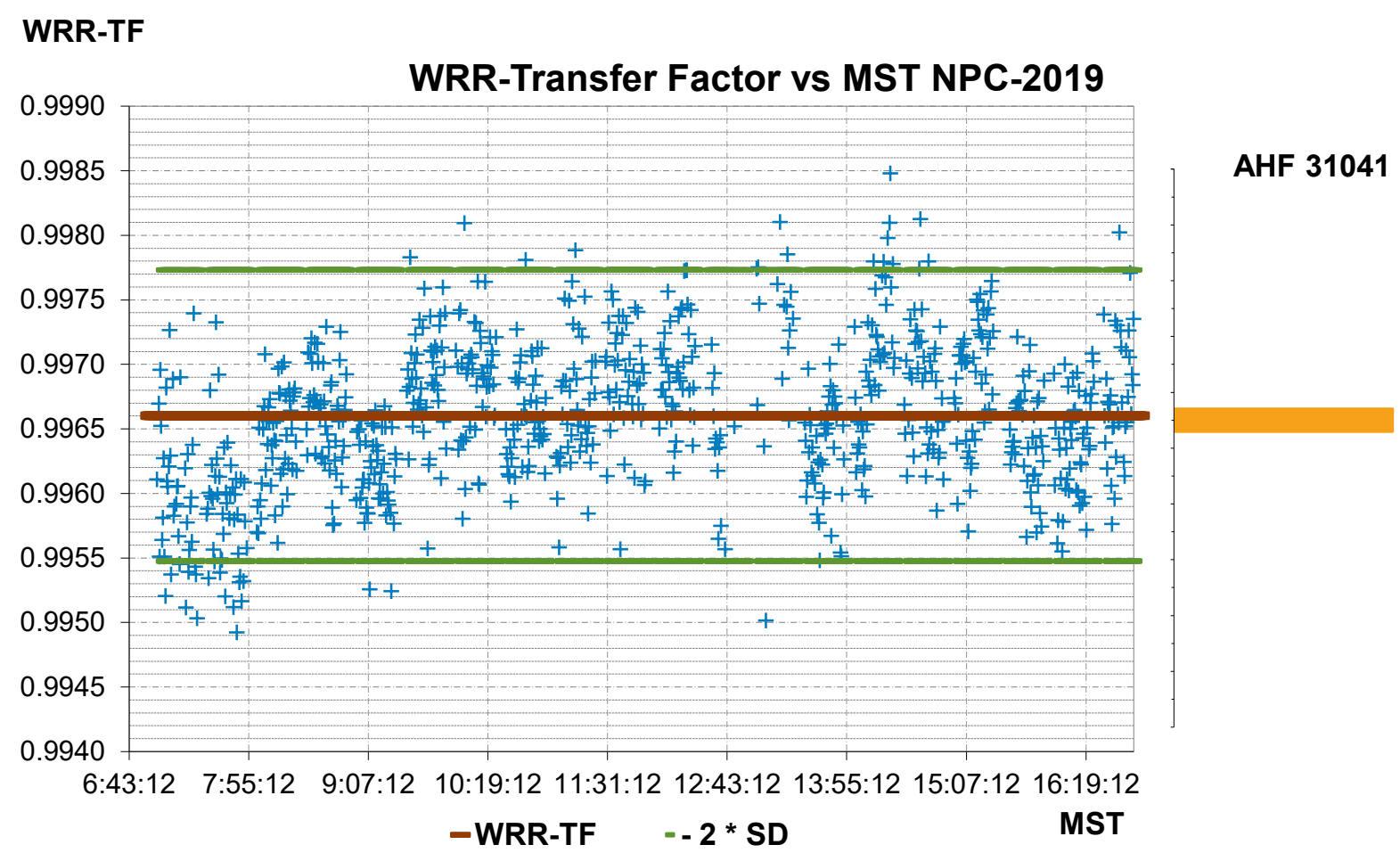

Figure 11. WRR-Transfer Factor vs. Mountain Standard Time NPC-2019 for AHF 31041

\section{WRR-TF}

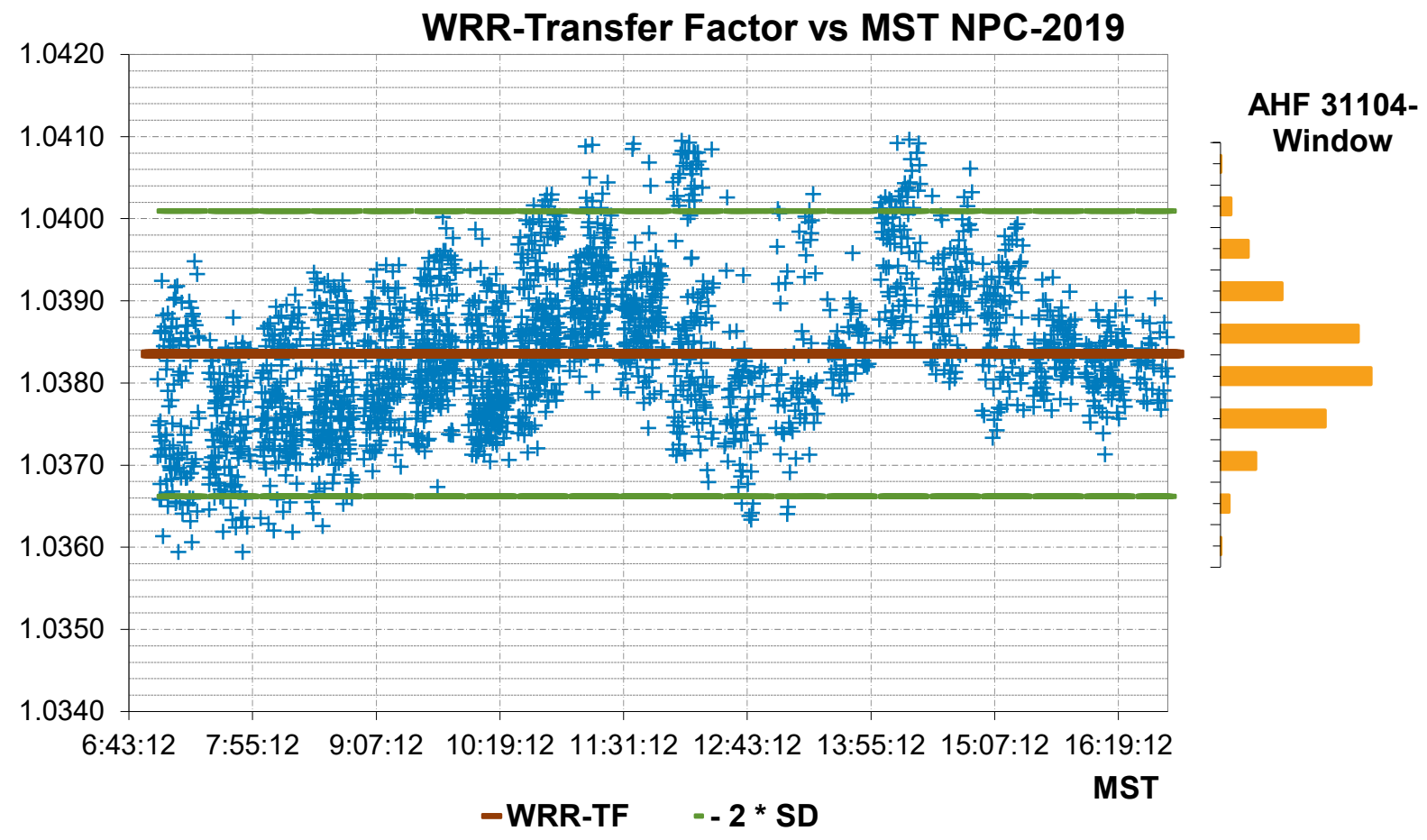

Figure 12. WRR-Transfer Factor vs. Mountain Standard Time NPC-2019 for AHF 31104-Window 


\section{WRR-TF}

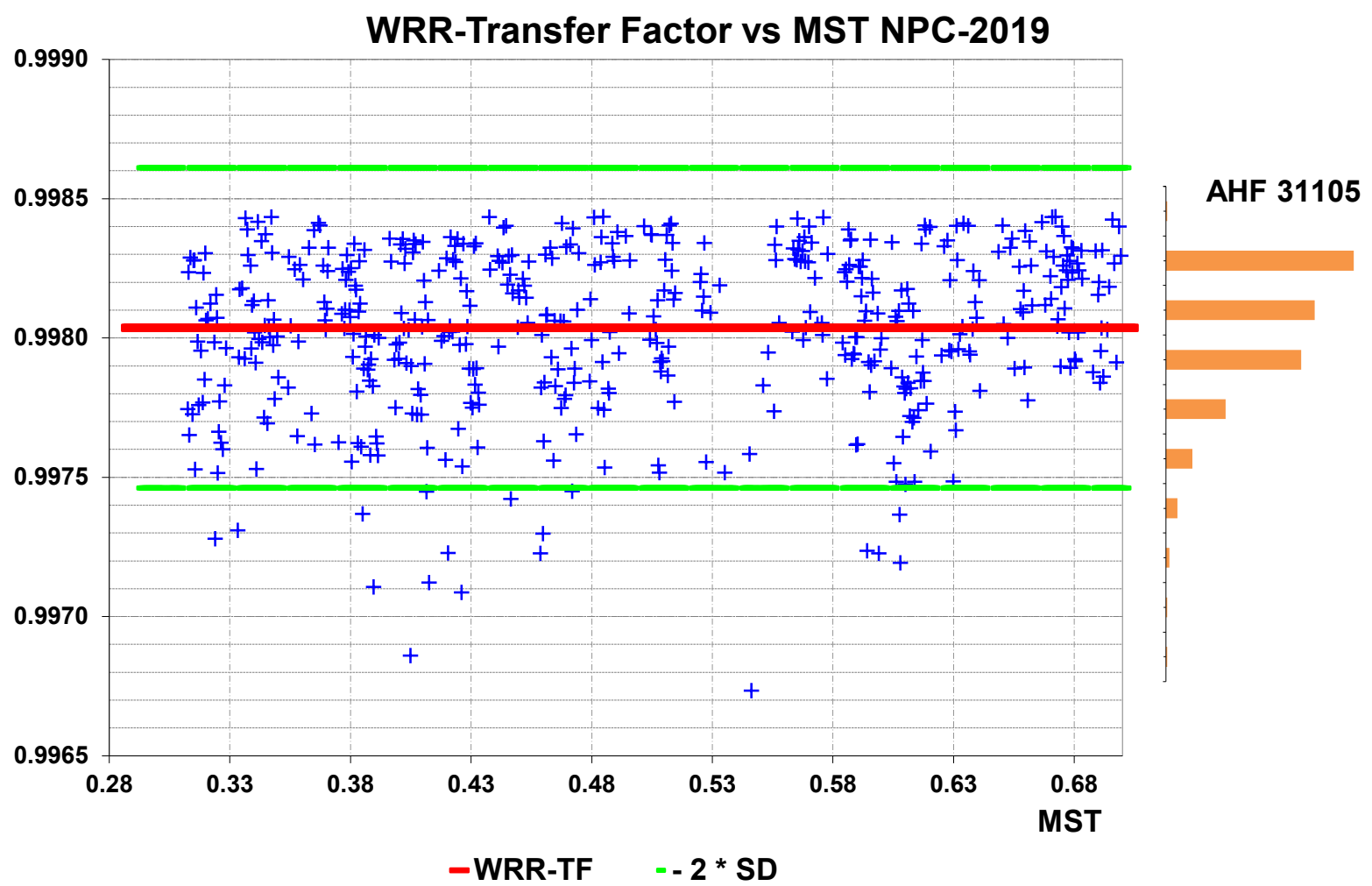

Figure 13. WRR-Transfer Factor vs. Mountain Standard Time NPC-2019 for AHF 31105

\section{WRR-TF}

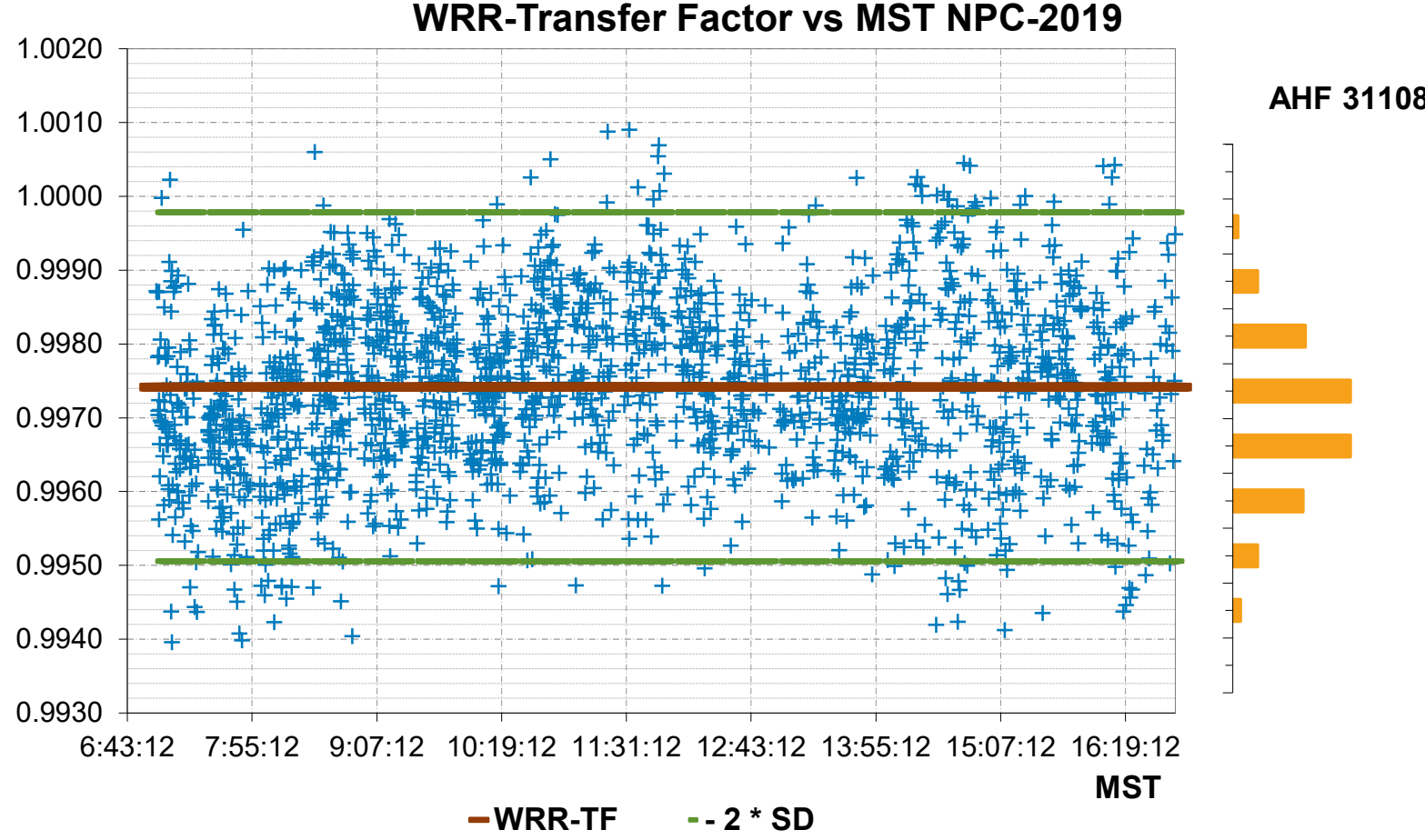

Figure 14. WRR-Transfer Factor vs. Mountain Standard Time NPC-2019 for AHF 31108 


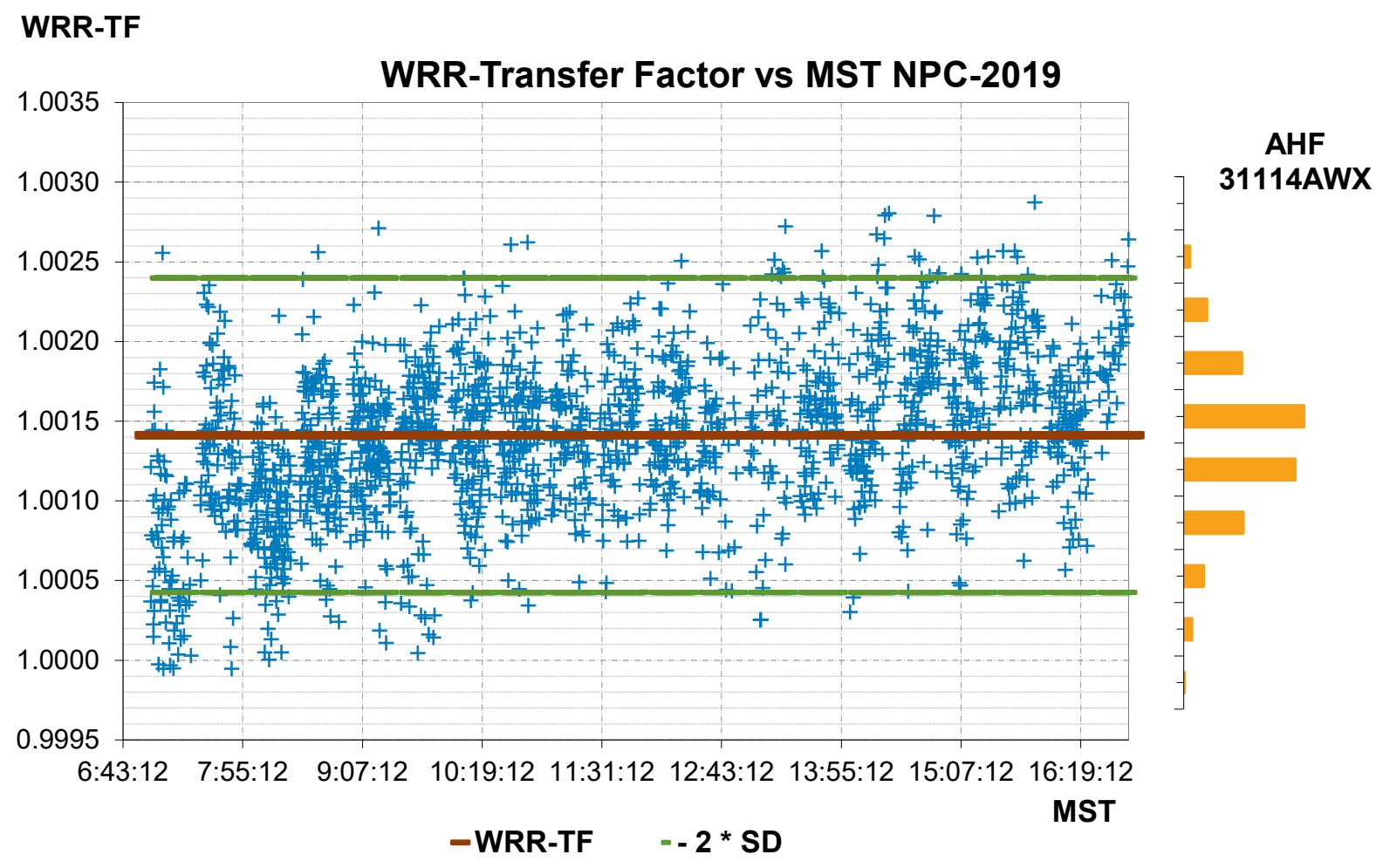

Figure 15. WRR-Transfer Factor vs. Mountain Standard Time NPC-2019 for AHF 31114AWX

\section{WRR-TF}

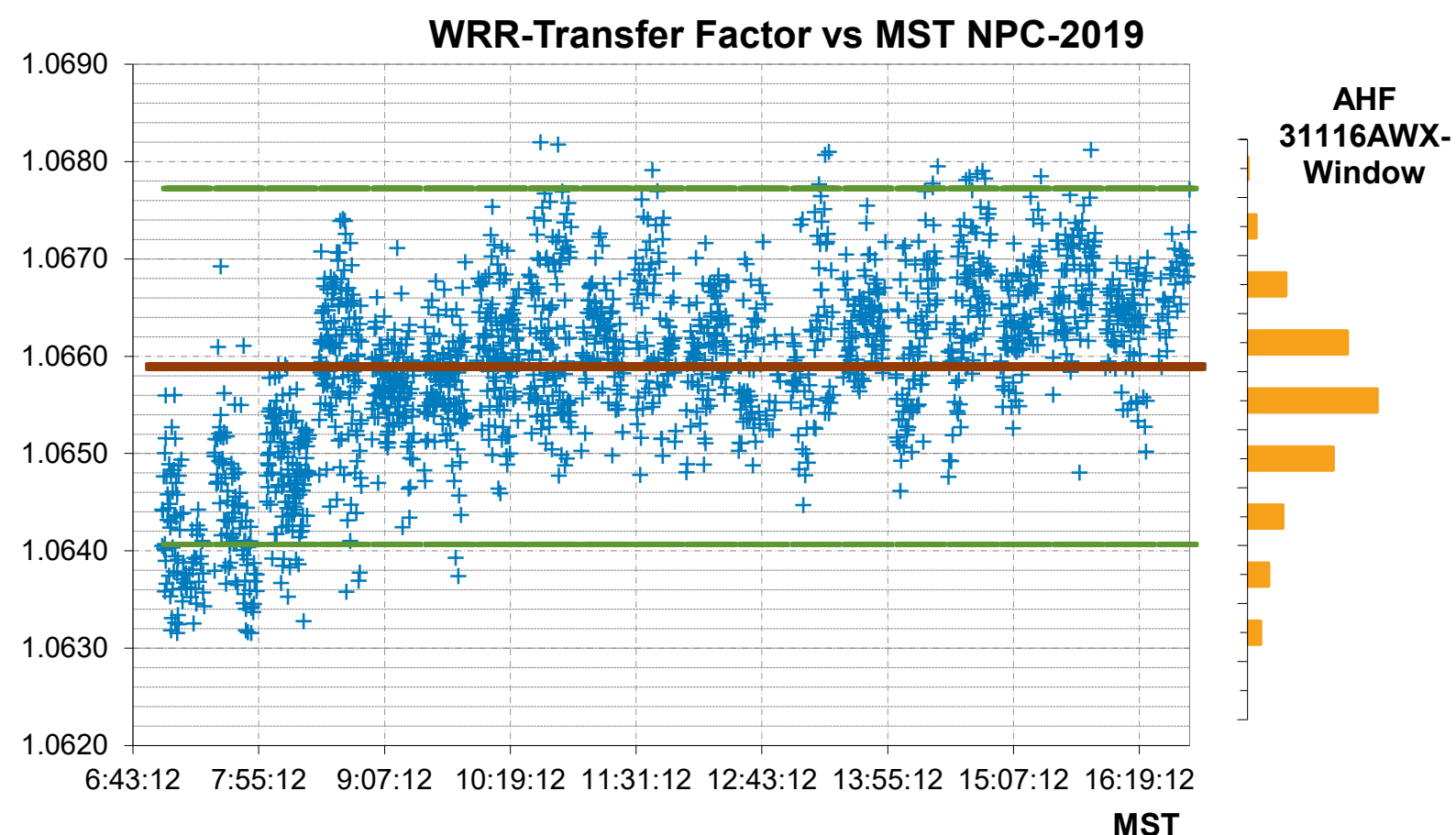

-WRR-TF - - 2 * SD

Figure 16. WRR-Transfer Factor vs. Mountain Standard Time NPC-2019 for AHF 31116AWX-Window 


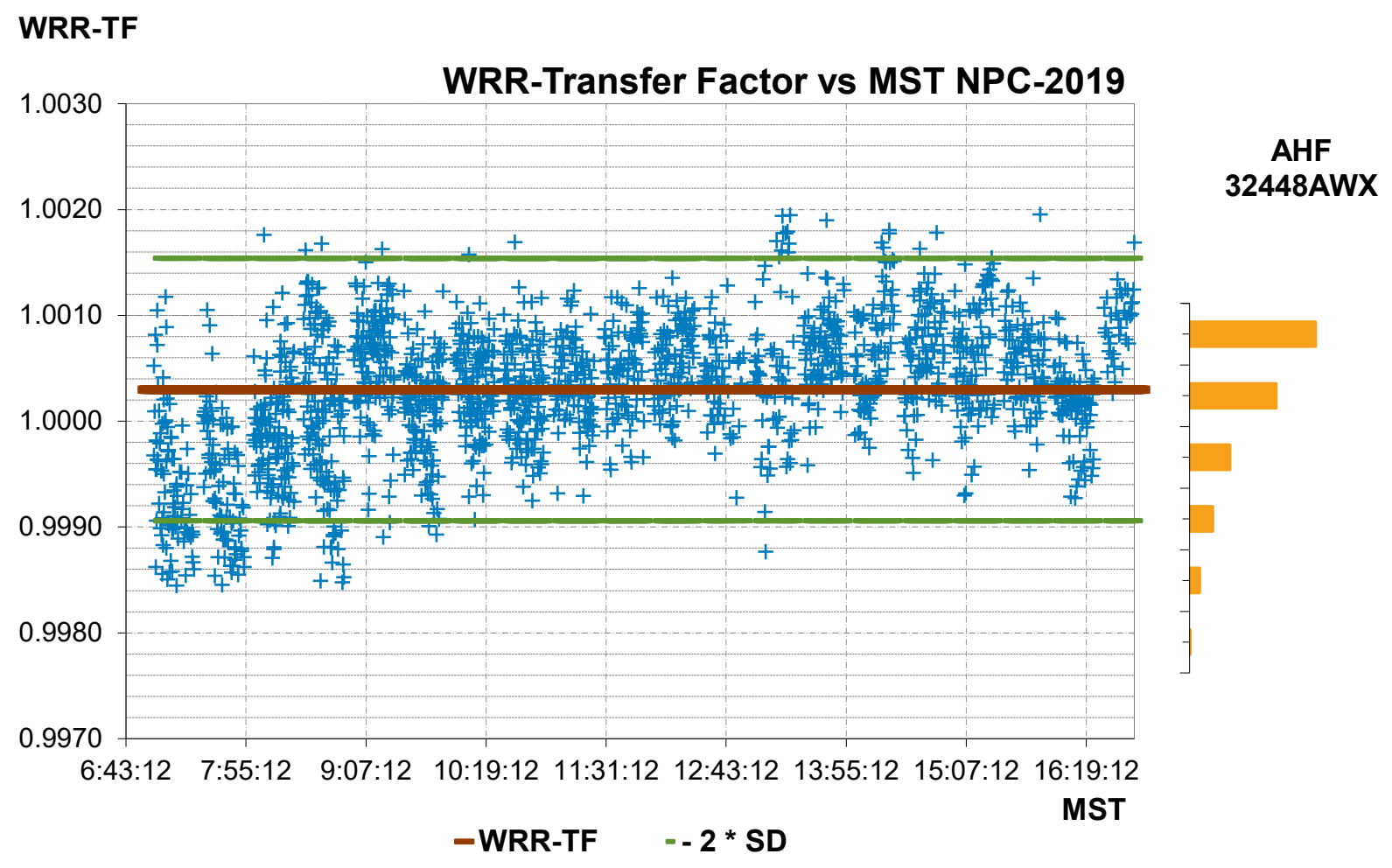

Figure 17. WRR-Transfer Factor vs. Mountain Standard Time NPC-2019 for AHF 31116AWX-Window WRR-TF

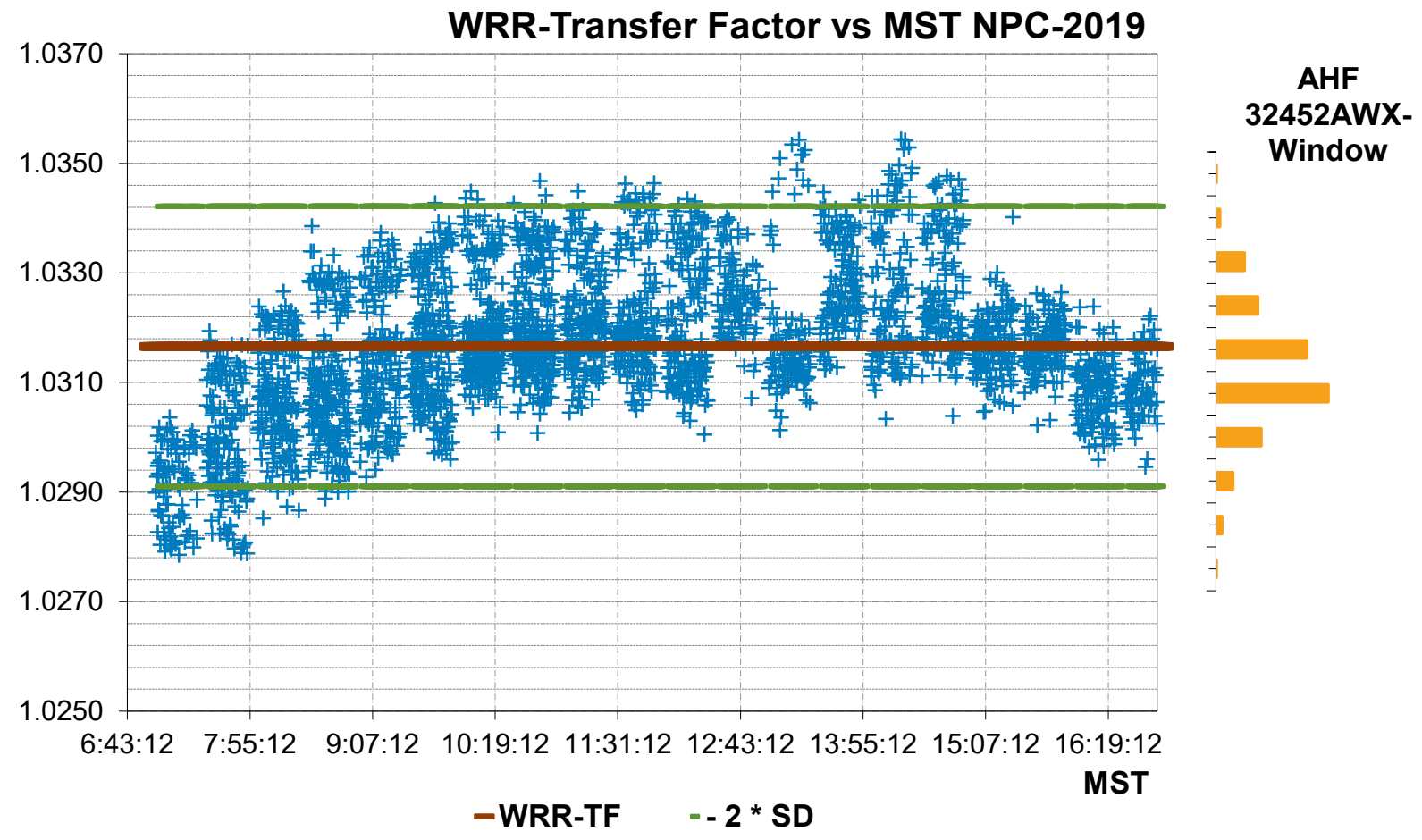

Figure 18. WRR-Transfer Factor vs. Mountain Standard Time NPC-2019 for AHF 32452AWX-Window 


\section{WRR-TF}

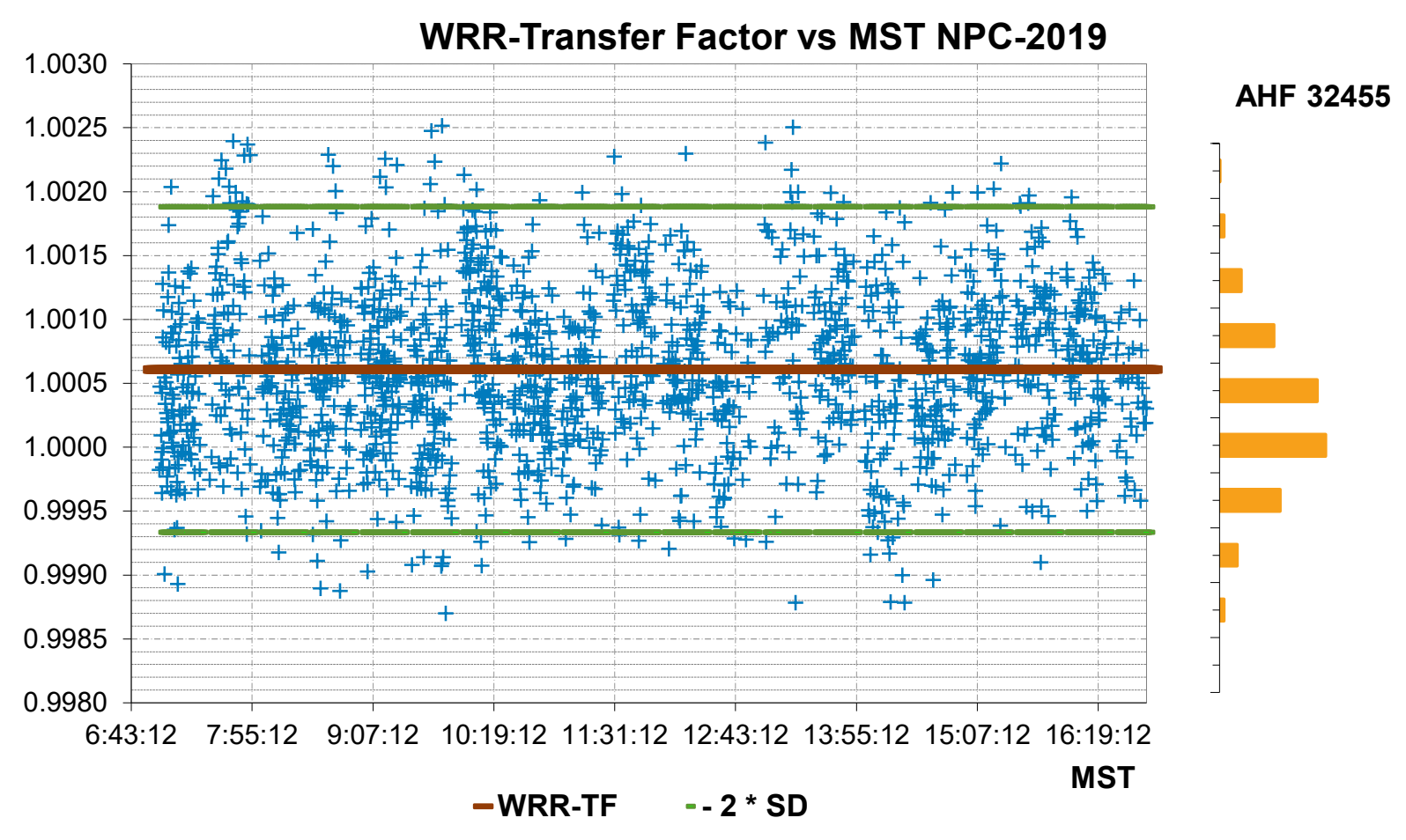

Figure 19. WRR-Transfer Factor vs. Mountain Standard Time NPC-2019 for AHF 32455

WRR-TF

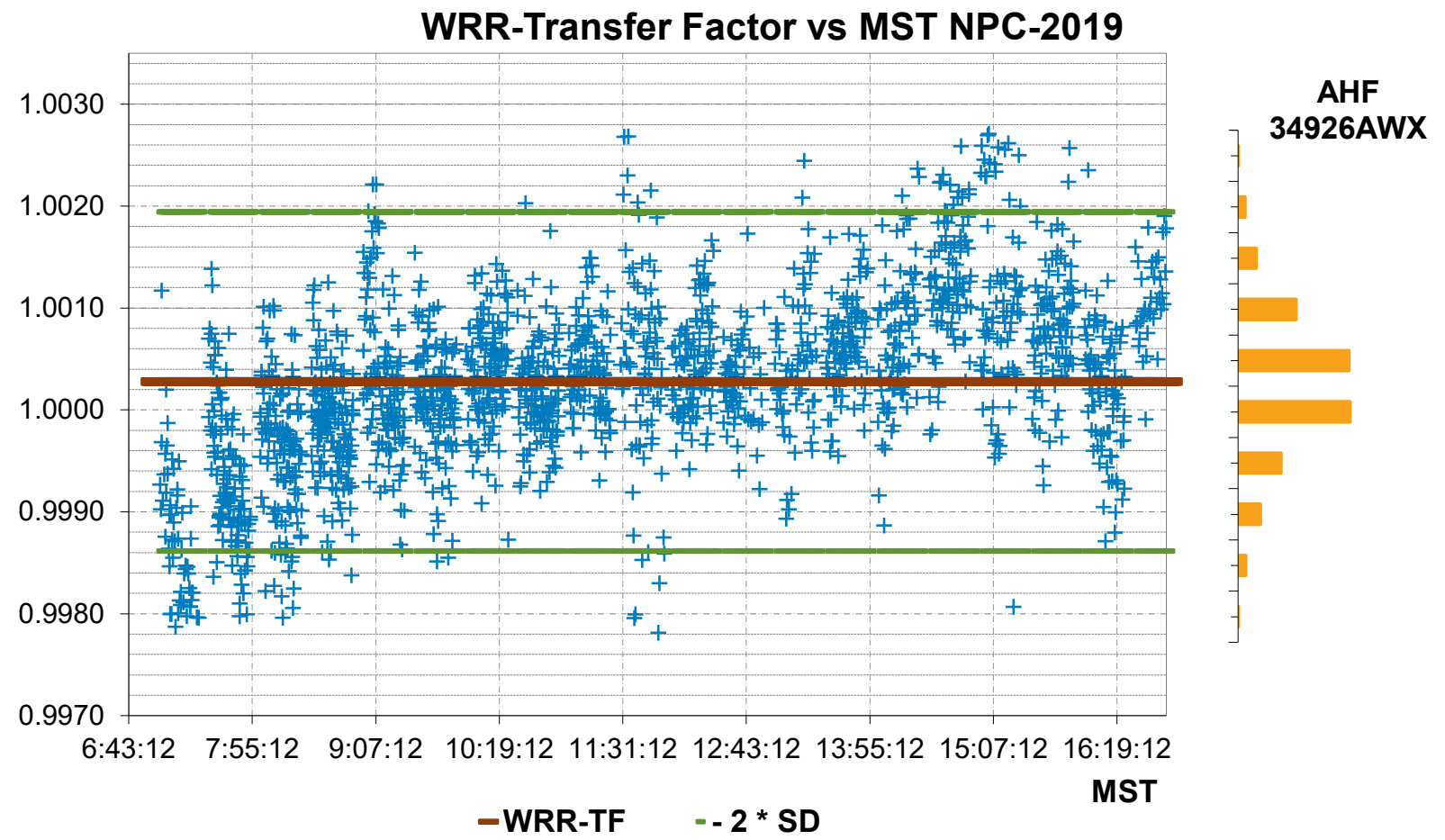

Figure 20. WRR-Transfer Factor vs. Mountain Standard Time NPC-2019 for AHF 34926AWX 


\section{WRR-TF}

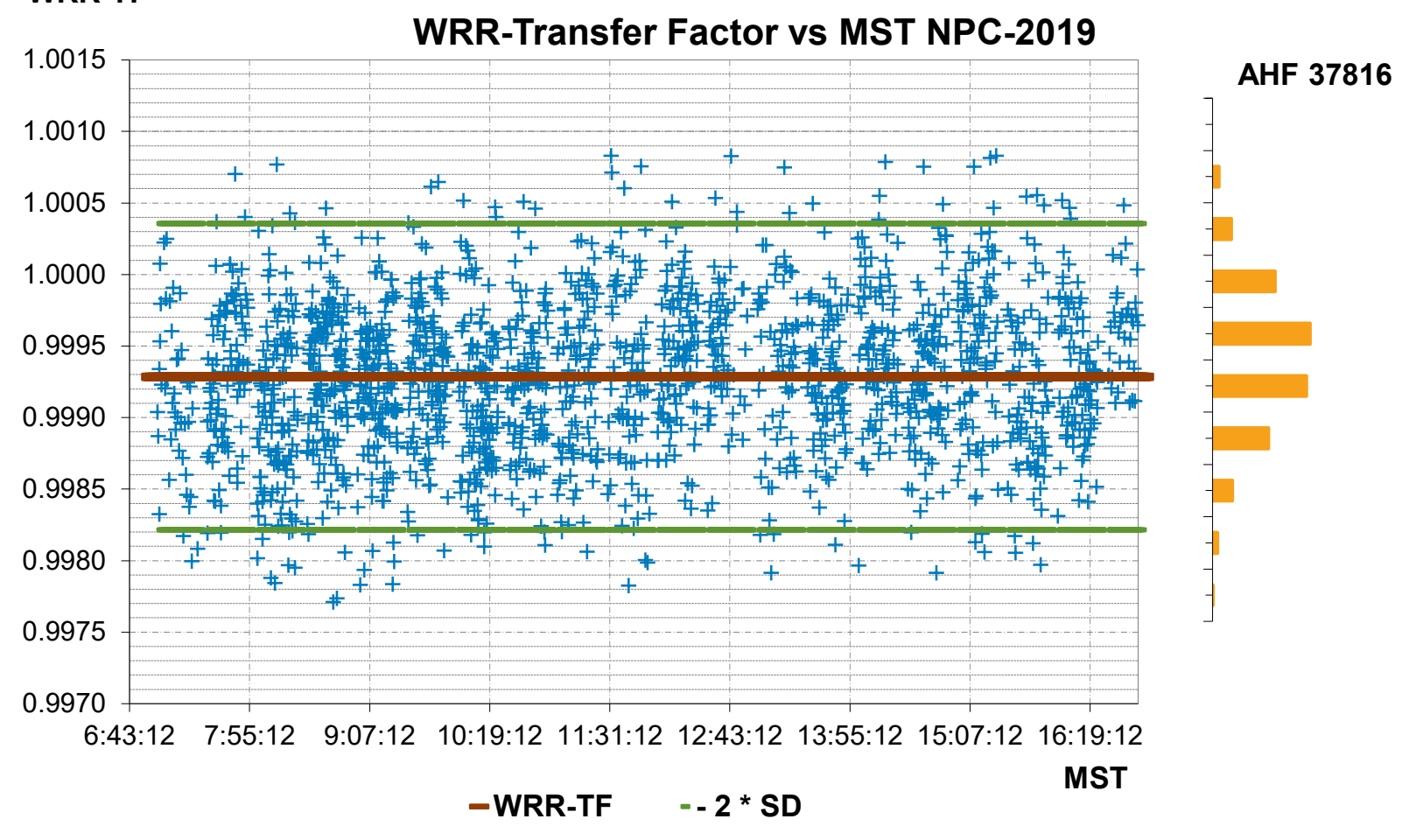

Figure 21. WRR-Transfer Factor vs. Mountain Standard Time NPC-2019 for AHF 37816

\section{WRR-TF}

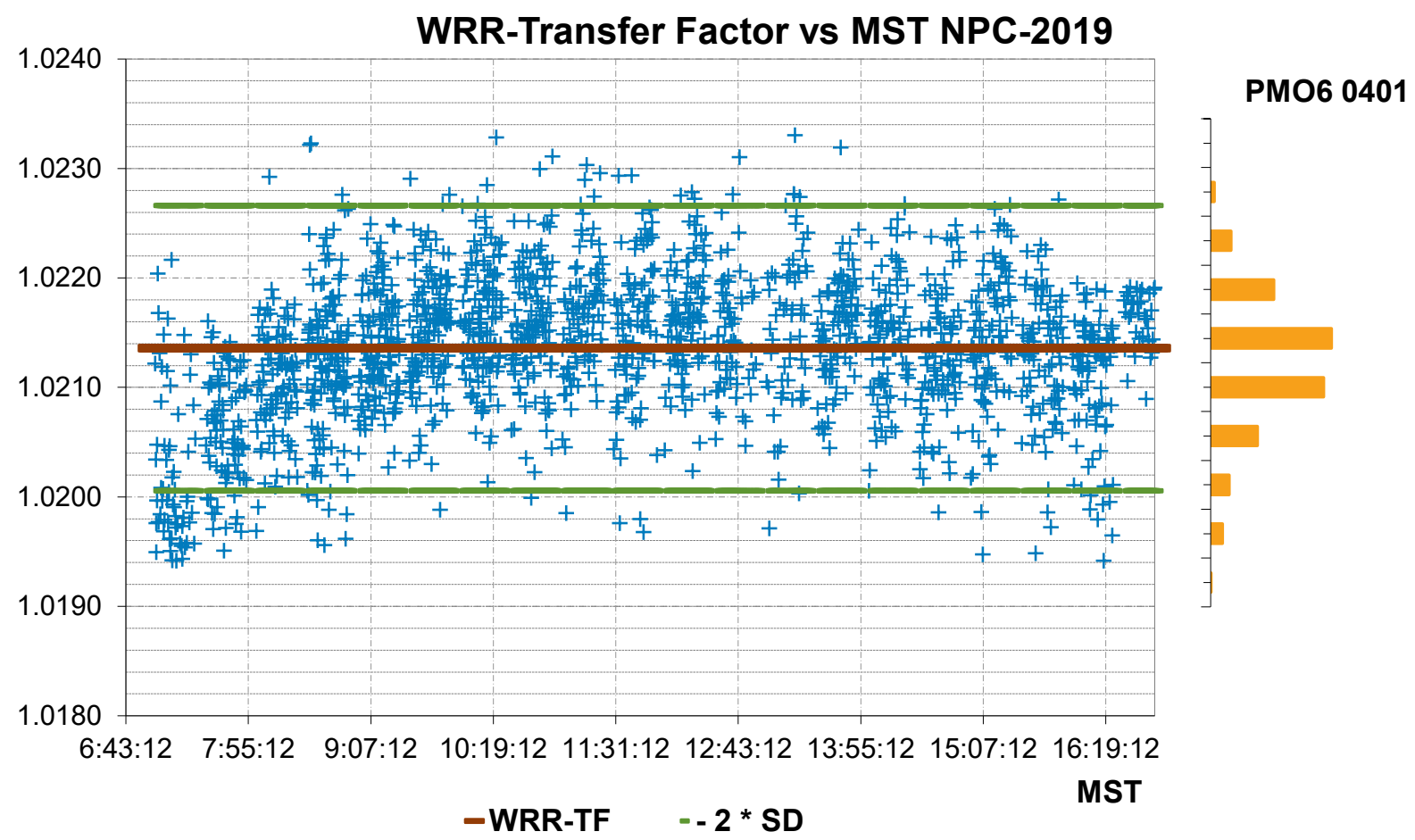

Figure 22. WRR-Transfer Factor vs. Mountain Standard Time NPC-2019 for PMO6 0401 


\section{WRR-TF}

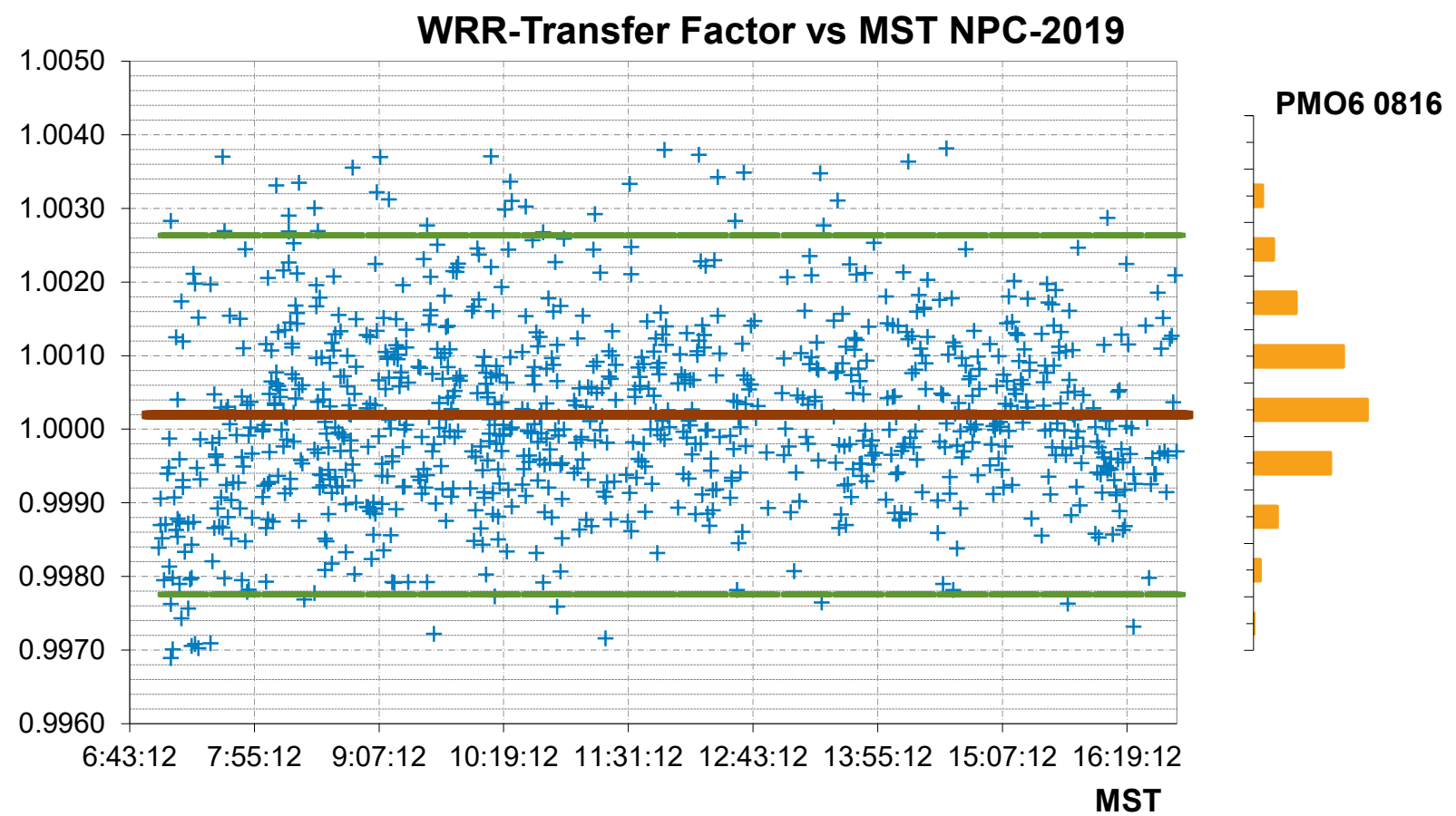

Figure 23. WRR-Transfer Factor vs. Mountain Standard Time NPC-2019 for PMO6 0816

\section{WRR-TF}

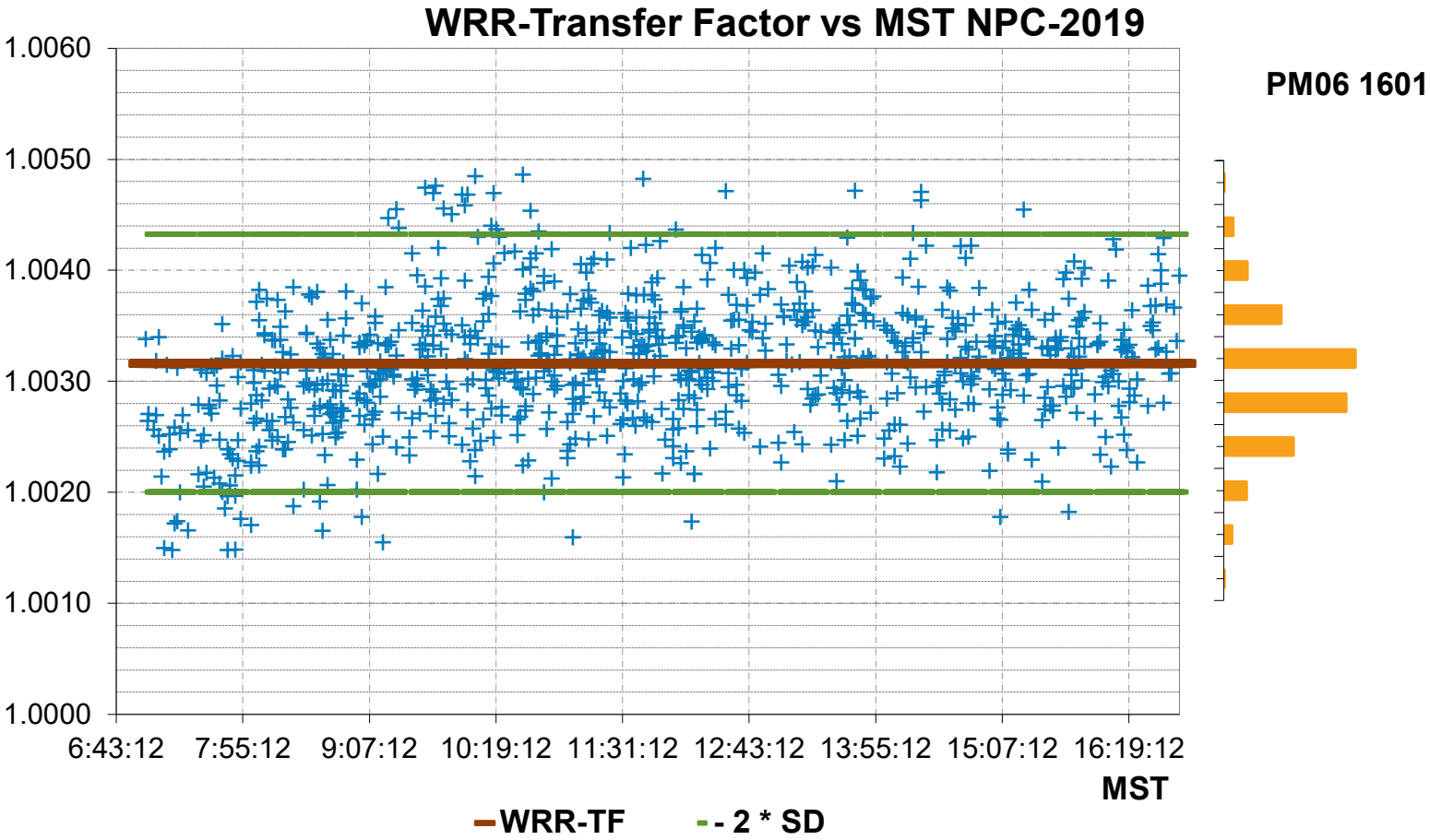

Figure 24. WRR-Transfer Factor vs. Mountain Standard Time NPC-2019 for PMO6 1601 


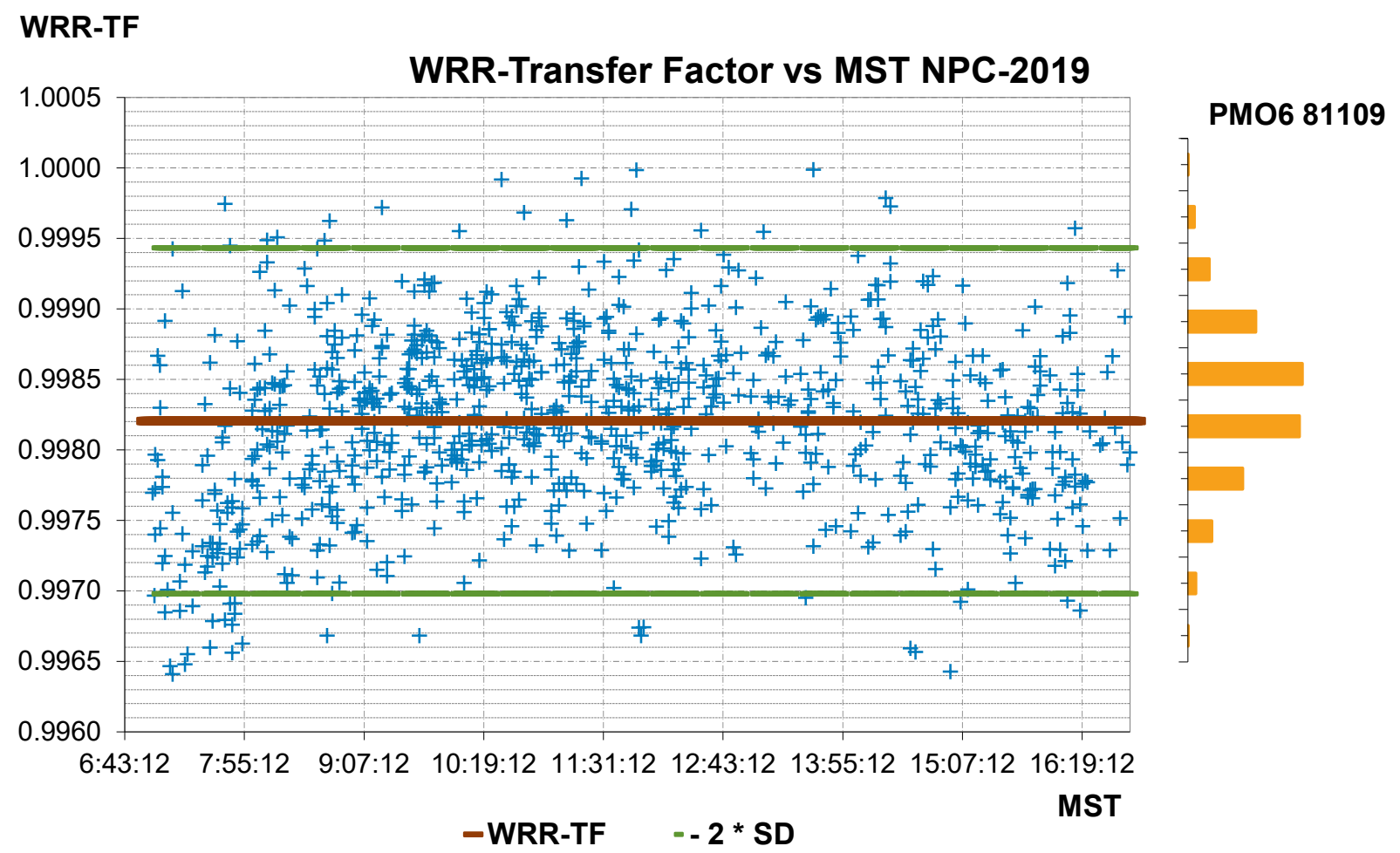

Figure 25. WRR-Transfer Factor vs. Mountain Standard Time NPC-2019 for PMO6 81109

WRR-TF

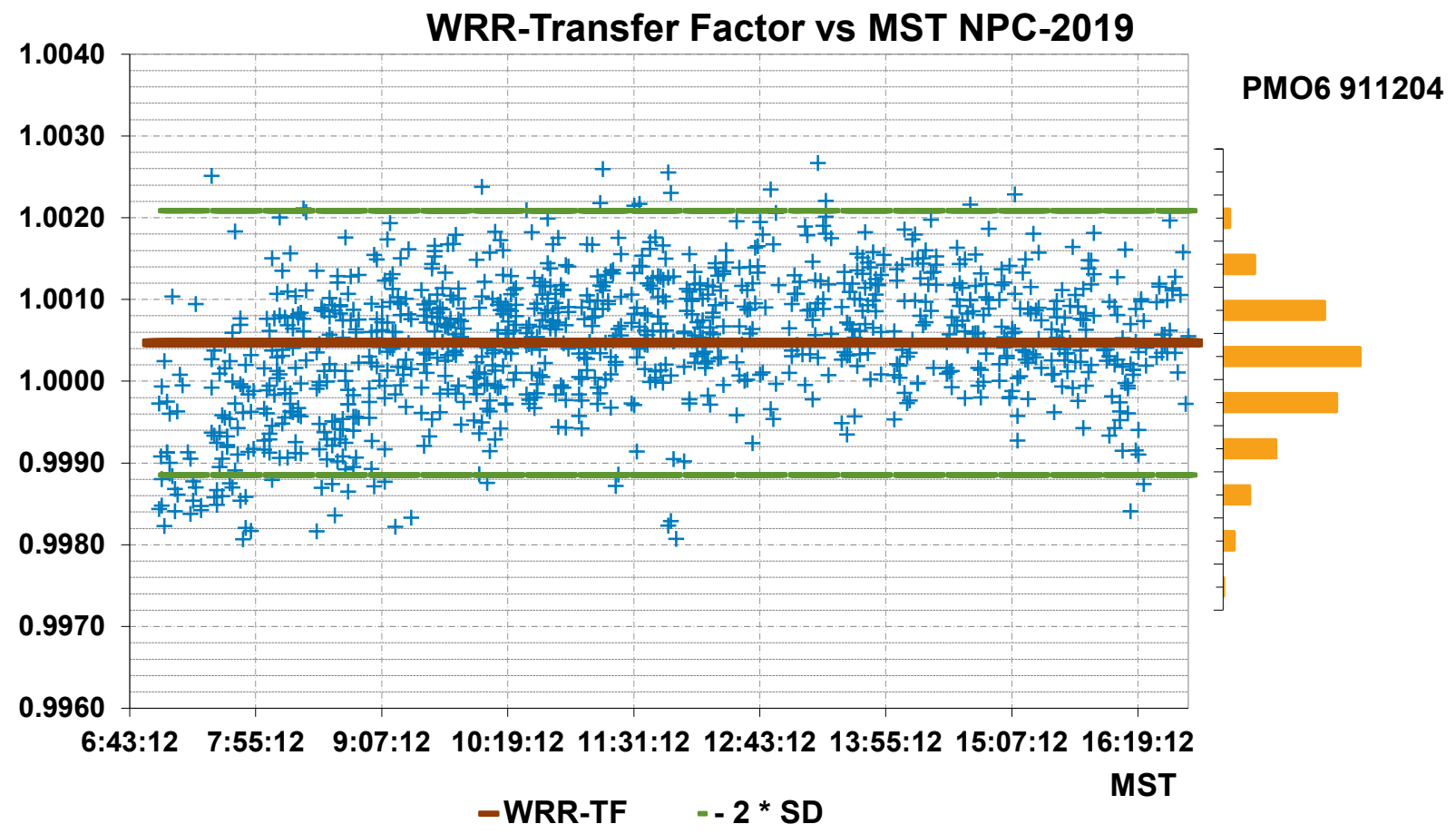

Figure 26. WRR-Transfer Factor vs. Mountain Standard Time NPC-2019 for PMO6 911204 
WRR-TF

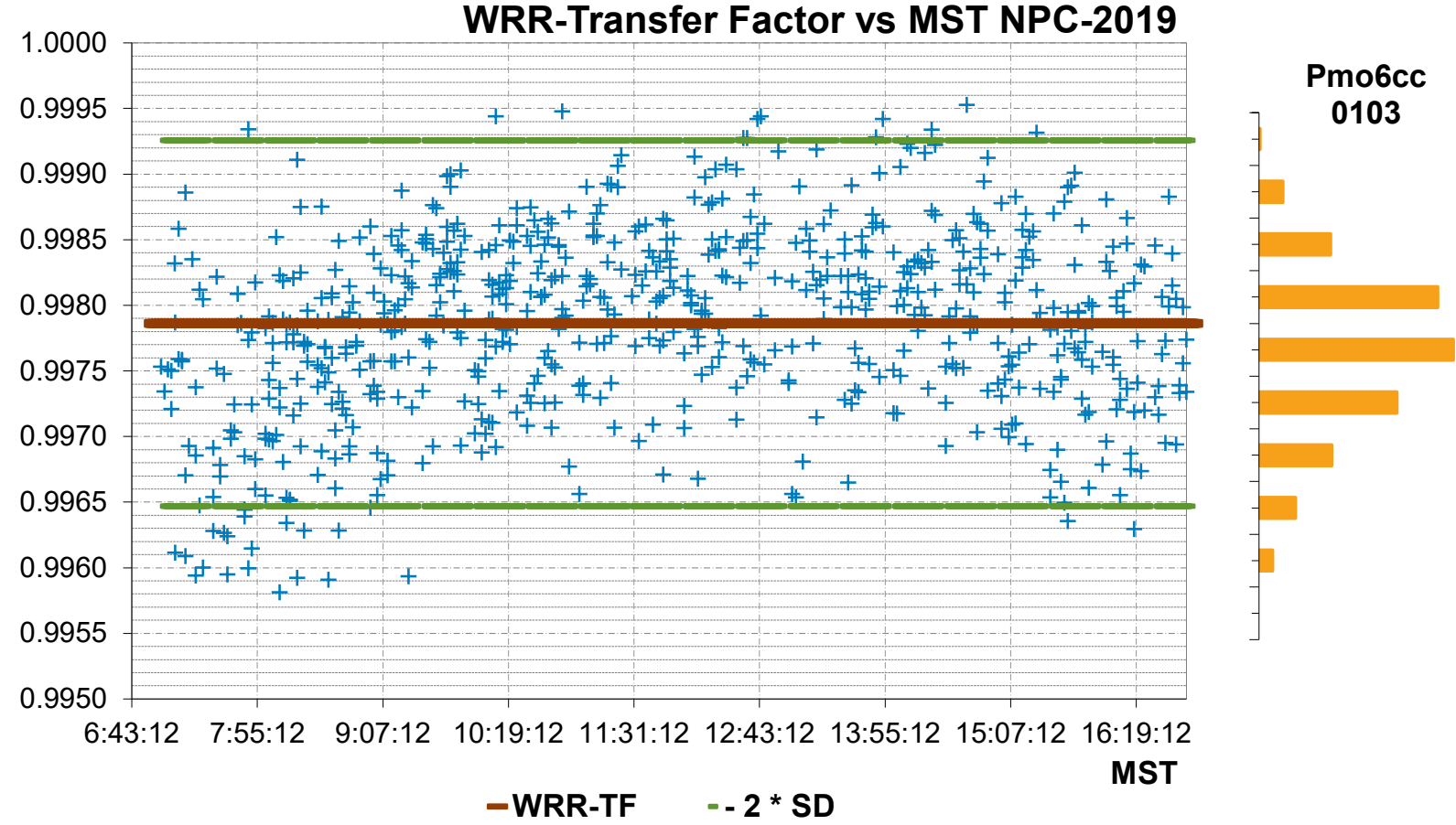

Figure 27. WRR-Transfer Factor vs. Mountain Standard Time NPC-2019 for PMO6cc 0103

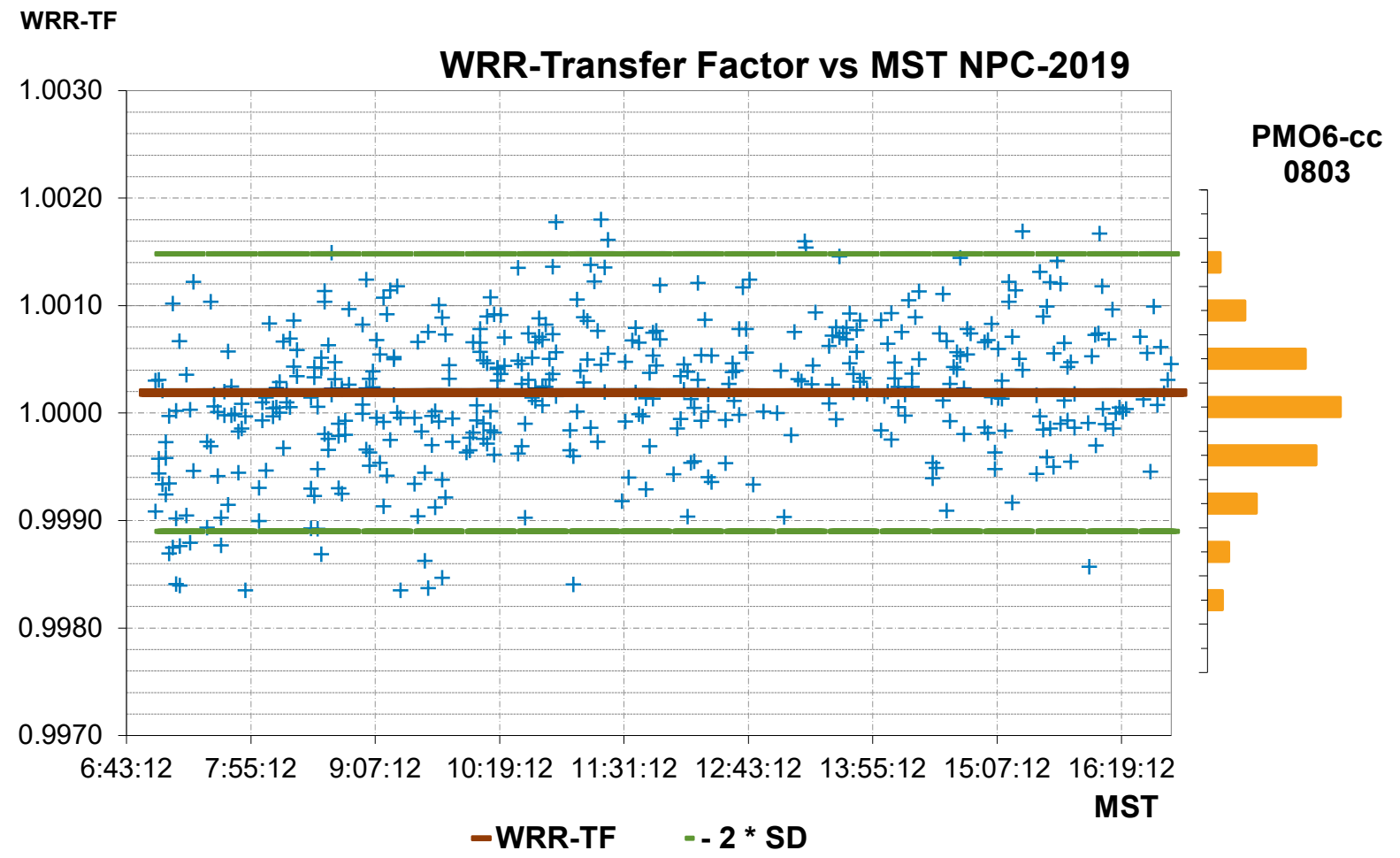

Figure 28. WRR-Transfer Factor vs. Mountain Standard Time NPC-2019 for PMO6cc 0803 


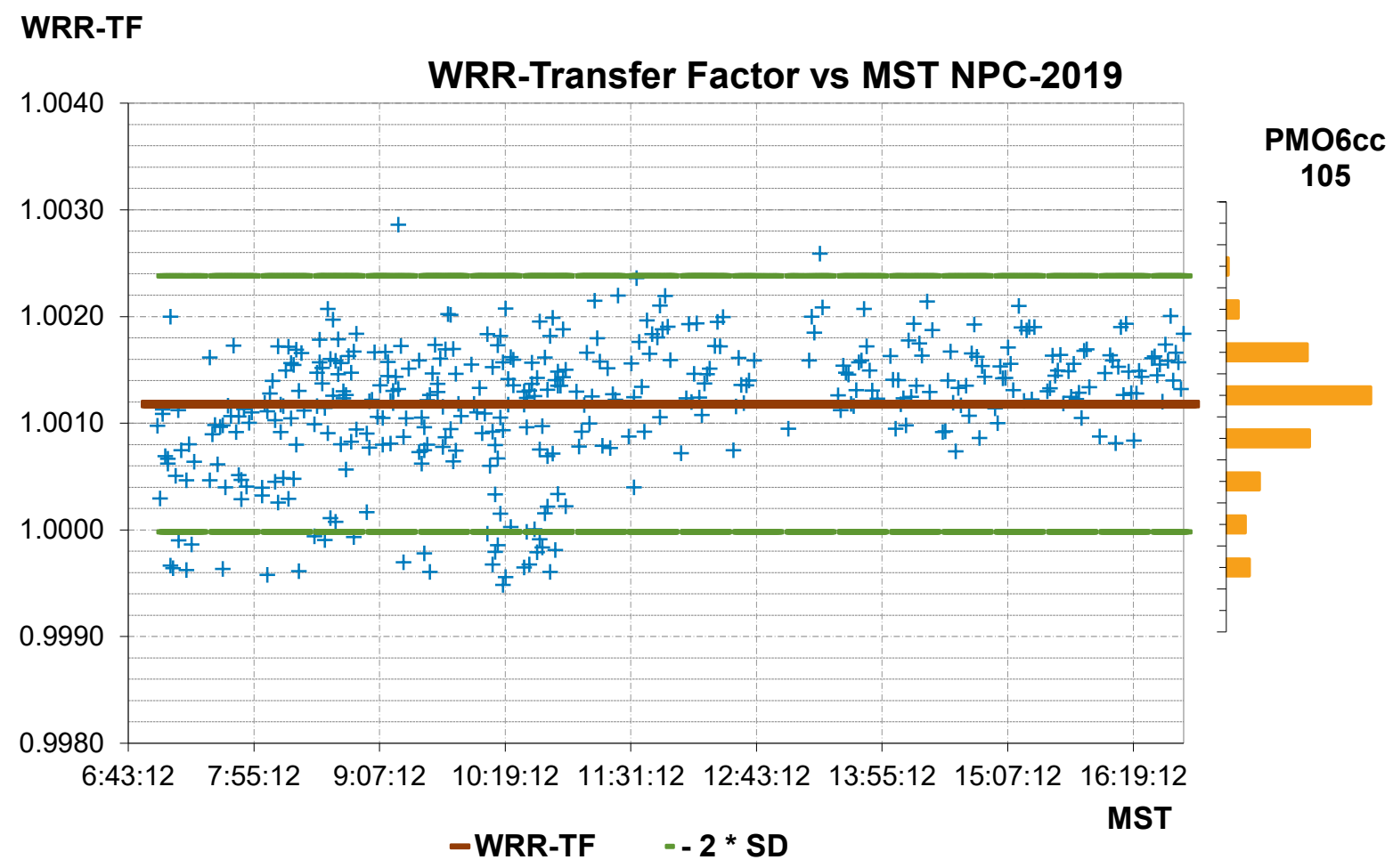

Figure 29. WRR-Transfer Factor vs. Mountain Standard Time NPC-2019 for PMO6-cc 105

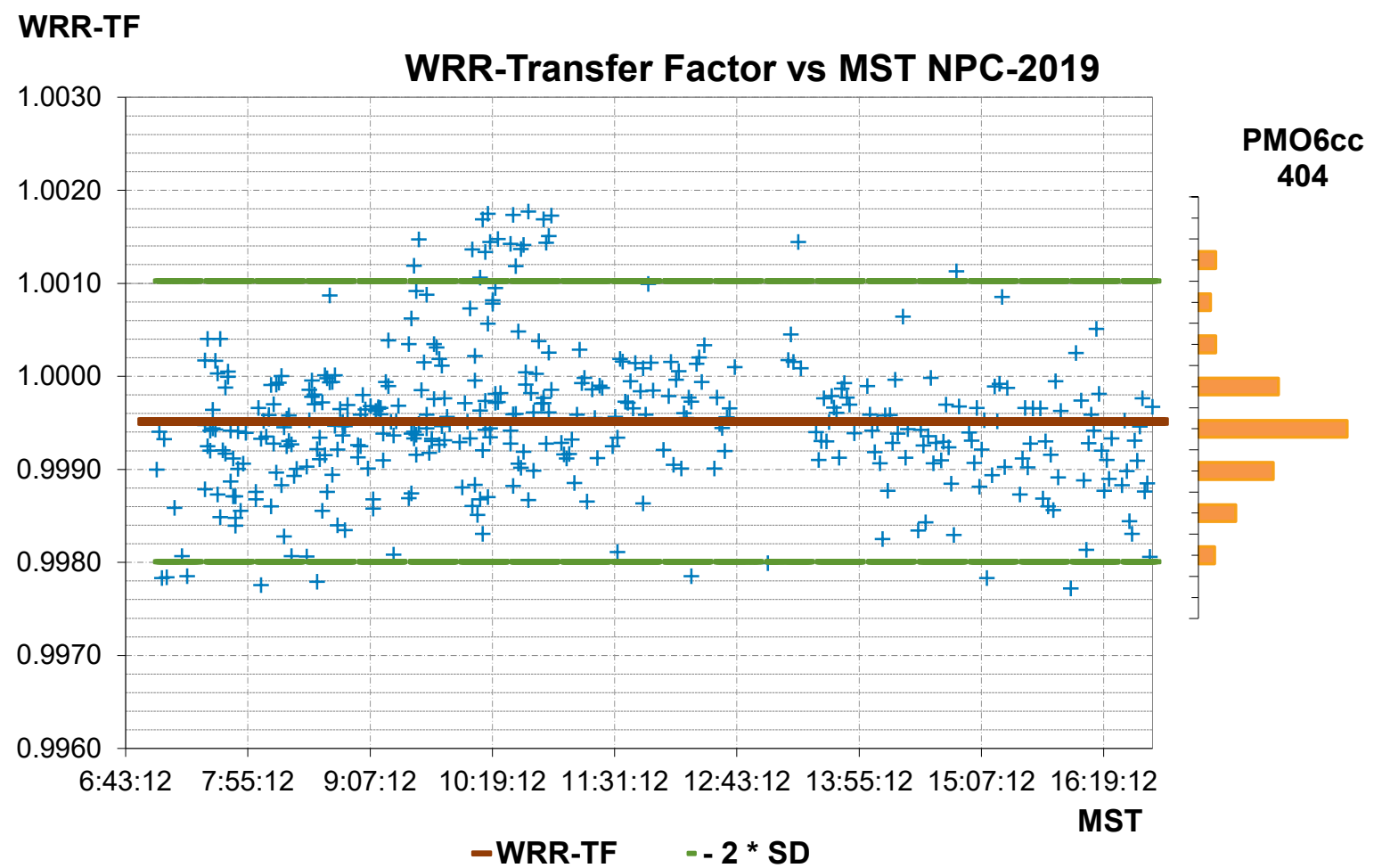

Figure 30. WRR-Transfer Factor vs. Mountain Standard Time NPC-2019 for PMO6cc 404 


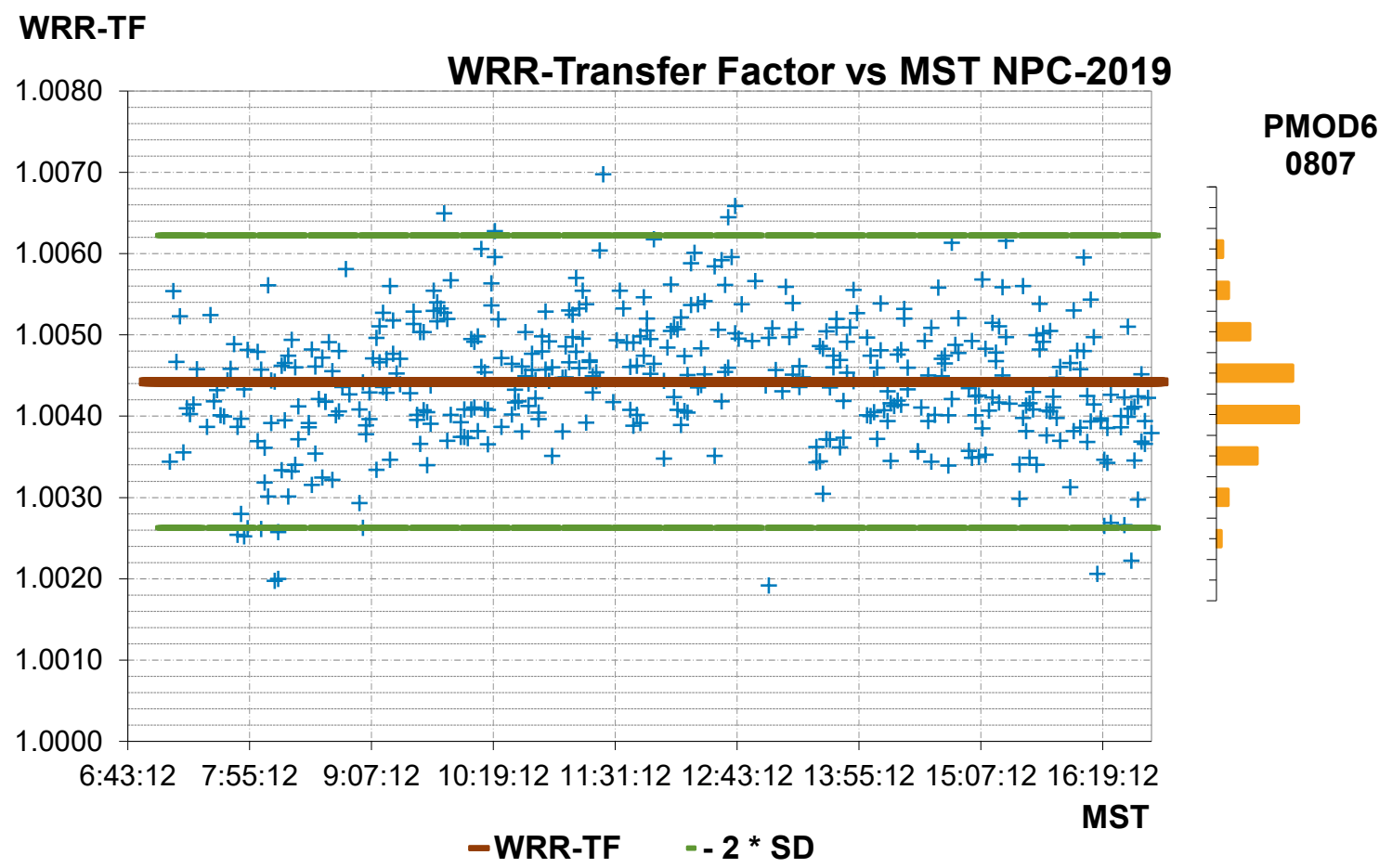

Figure 31. WRR-Transfer Factor vs. Mountain Standard Time NPC-2019 for PMOD6 0806

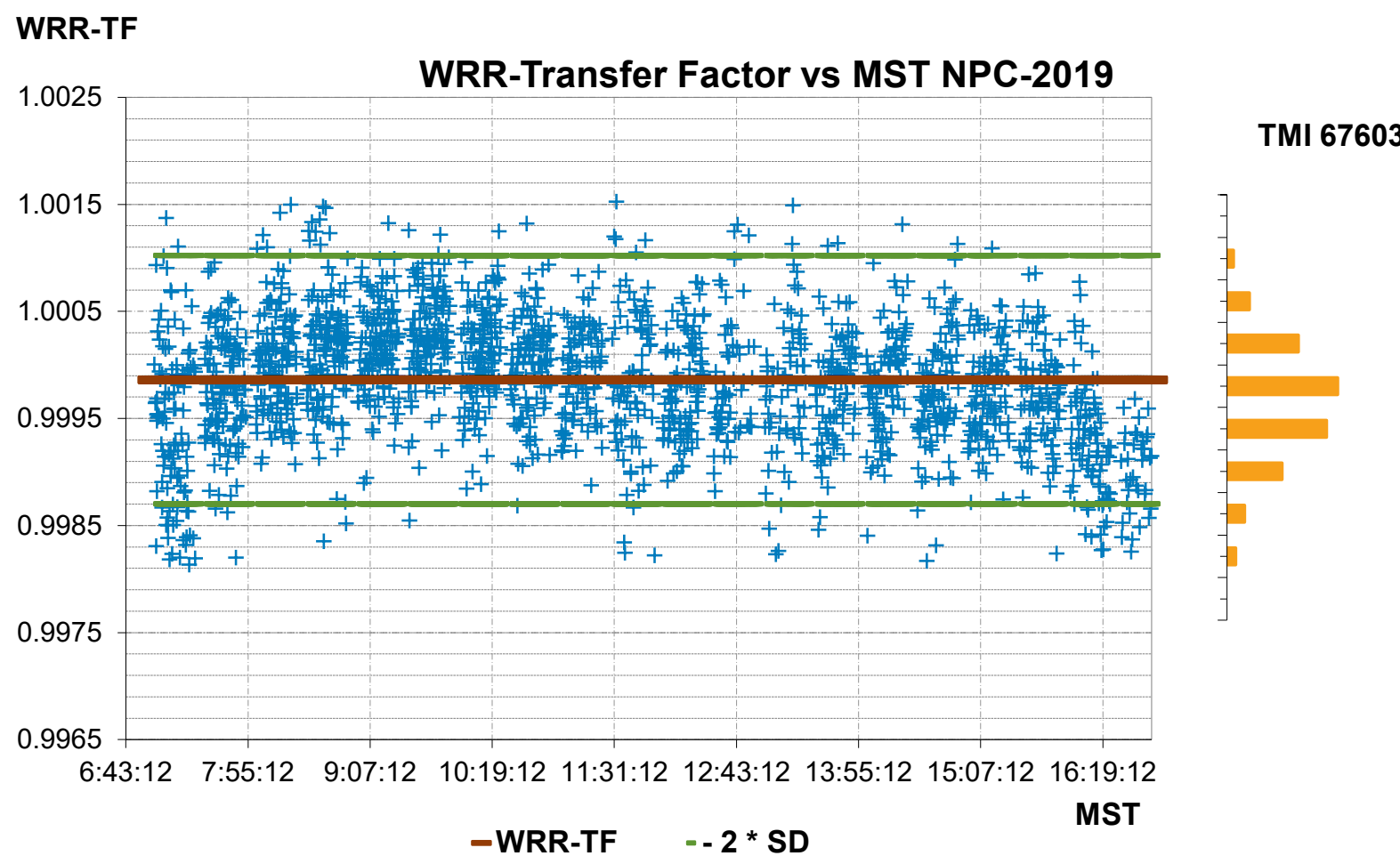

Figure 32. WRR-Transfer Factor vs. Mountain Standard Time NPC-2019 for TMI 67603 


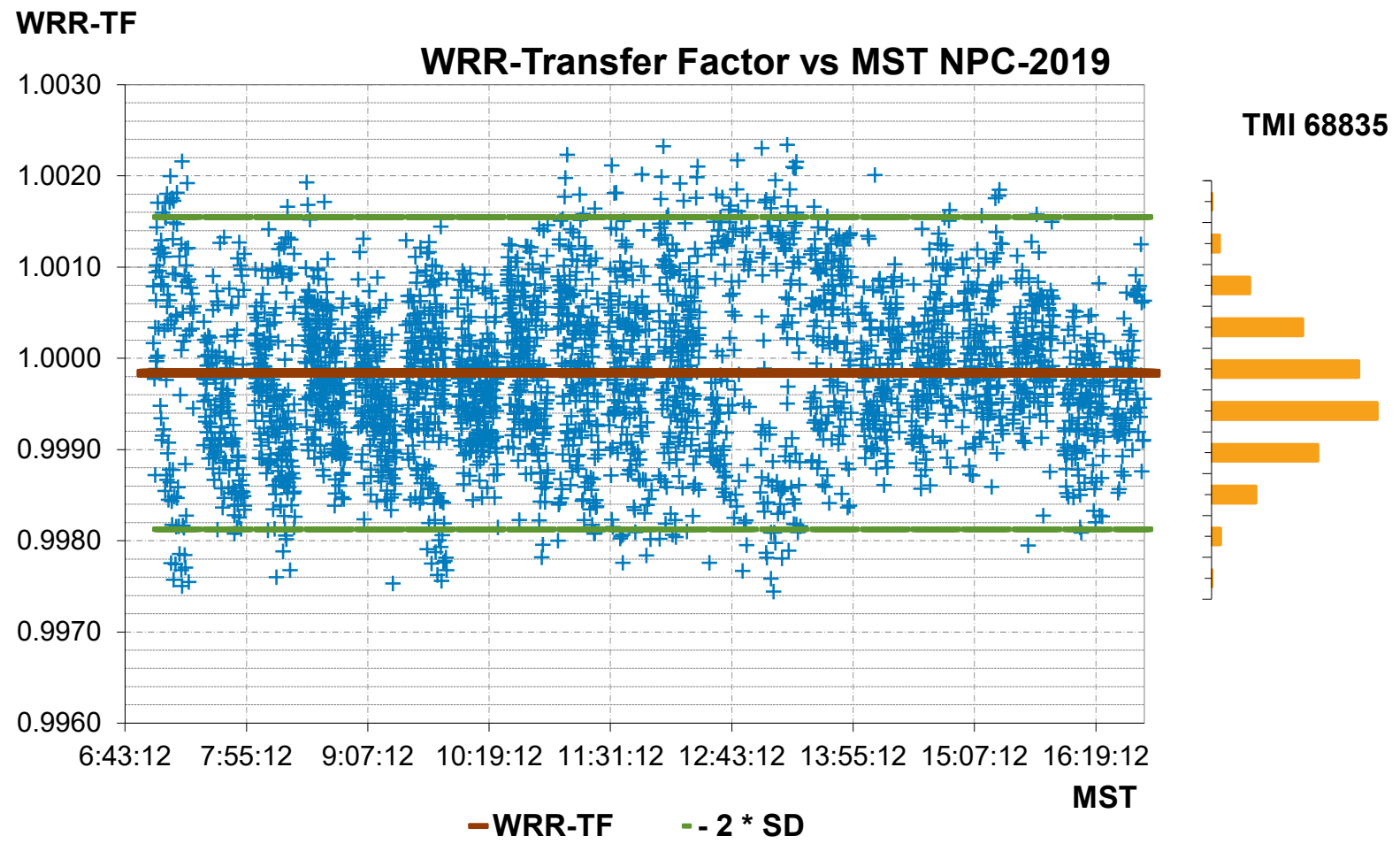

Figure 33. WRR-Transfer Factor vs. Mountain Standard Time NPC-2019 for TMI 68835

\subsection{Recommendations}

As a result of the comparisons made during NPC-2019, we suggest participants observe the following measurement practices:

- For the purpose of pyrheliometer comparisons, such as NPC-2019, we recommend the user apply only the manufacturer's calibration factor, not the WRR-TF or the new calibration factor, to report his or her absolute cavity radiometer's irradiance readings. Doing so eliminates the possibility of compounding WRR factors from previous comparisons.

- For data collection in the field, the manufacturer's calibration factor should be used to calculate the cavity responsivity. Each irradiance reading should then be multiplied by the appropriate WRR-TF to provide homogeneity of solar radiation measurements that are traceable to the WRR. We recommend this approach to realize the benefits of participating in the NPC. 


\section{Ancillary Data}

The environmental conditions (i.e., temperature, relative humidity, barometric pressure, wind speed, precipitable water vapor, and spectral data) were measured during the NPC-2019 comparisons using the meteorological station at the SRRL. Additional information, including Baseline Measurement System data and graphical summaries, can be found on the Measurements and Instrumentation Data Center website. ${ }^{5}$

Time-series plots and other graphical presentations of these data collected during the pyrheliometer comparisons are presented in Appendix B.

${ }^{5}$ http:www.nrel.gov/mide/srrl bms/ 


\section{References}

Finsterle, W. 2019. WMO International Pyrheliometer Comparison, IPC-XII, 28 September16 October 2015: Final Report. WMO IOM Report No. 124. Davos, Switzerland; 98 pp.

Fröhlich, C. 1991. "History of Solar Radiometry and the World Radiometric Reference." Metrologia 28(3): 111-115.

Reda, I. 1996. Calibration of a Solar Absolute Cavity Radiometer With Traceability to the World Radiometric Reference. Golden, CO: The National Renewable Energy Laboratory. NREL/TP463-20619. https://doi.org/10.2172/15000940.

Reda, I., D. Myers, and T. Stoffel. 2008. "Uncertainty Estimate for the Outdoor Calibration of Solar Pyranometers: A Metrologist Perspective.” NCSLI Measure: The Journal of Measurement Science 3(4): 58-66. https://doi.org/10.1080/19315775.2008.11721448.

Romero, J. 1995. Direct Solar Irradiance Measurements with Pyrheliometers:

Instruments and Calibrations. IPC-VIII. Davos, Switzerland; 16 pp.

Romero, J., N.P. Fox, and C. Fröhlich. 1996. "Improved Comparison of the World Radiometric Reference and the SI Radiometric Scale.” Metrologia 32(6): 523-524.

Physikalisch-Meteorologisches Observatorium Davos_-World Radiation Center (PMOD/WRC). 1996. International Pyrheliometer Comparison, IPC VIII, 25 September-13 October 1995, Results and Symposium. Working Report No. 188. Davos Dorf, Switzerland: Swiss Meteorological Institute; $115 \mathrm{pp}$. 


\section{Appendix A. List of Participants and Pyrheliometers}

Table A-1. List of Participants and Pyrheliometers

\begin{tabular}{|c|c|c|c|}
\hline $\begin{array}{l}\text { Serial Number } \\
\text { of Radiometer }\end{array}$ & Operator 1 & Operator 2 & Affiliation \\
\hline PMO6cc 105 & Irene Melero Asensio & $\mathrm{n} / \mathrm{a}$ & AEMET \\
\hline PMO6cc 404 & Irene Melero Asensio & $\mathrm{n} / \mathrm{a}$ & AEMET \\
\hline AHF 17142 & Patrick Smith & Caitlin Hale & $\begin{array}{l}\text { Atlas Material Testing } \\
\text { Technology, LLC }\end{array}$ \\
\hline AHF 28556 & Patrick Smith & Caitlin Hale & $\begin{array}{l}\text { Atlas Material Testing } \\
\text { Technology, LLC }\end{array}$ \\
\hline PM06 1601 & Singh Ajay & $\mathrm{n} / \mathrm{a}$ & Campbell Scientific, Inc. \\
\hline AHF 29222 & Craig Webb & James Martin & $\begin{array}{l}\text { DOE Atmospheric } \\
\text { Radiation Measurement } \\
\text { (ARM) Program }\end{array}$ \\
\hline $\begin{array}{l}\text { AHF 30495- } \\
\text { Window }\end{array}$ & Craig Webb & James Martin & $\begin{array}{l}\text { DOE Atmospheric } \\
\text { Radiation Measurement } \\
\text { (ARM) Program }\end{array}$ \\
\hline PMO6 0816 & Ayako Imai & Makoto Shiobara & EKO Instruments \\
\hline AHF 14915 & Tom Kirk & $\mathrm{n} / \mathrm{a}$ & Eppley Laboratory, Inc. \\
\hline AHF 0000 & Wim Zaaiman & $\mathrm{n} / \mathrm{a}$ & $\begin{array}{l}\text { European Commission } \\
\text { Directorate General JRC }\end{array}$ \\
\hline PMO6 81109 & Wim Zaaiman & $\mathrm{n} / \mathrm{a}$ & $\begin{array}{l}\text { European Commission } \\
\text { Directorate General JRC }\end{array}$ \\
\hline PMO6 911204 & Wim Zaaiman & $\mathrm{n} / \mathrm{a}$ & $\begin{array}{l}\text { European Commission } \\
\text { Directorate General JRC }\end{array}$ \\
\hline TMI 68835 & Wim Zaaiman & $\mathrm{n} / \mathrm{a}$ & $\begin{array}{l}\text { European Commission } \\
\text { Directorate General JRC }\end{array}$ \\
\hline AHF 28560 & Erik Naranen & $\mathrm{n} / \mathrm{a}$ & ISO-CAL North America, LLC \\
\hline AHF 37816 & Erik Naranen & $\mathrm{n} / \mathrm{a}$ & ISO-CAL North America, LLC \\
\hline AHF 30110 & Mohammed Al Harbi & Sultan Bin Gasem & $\begin{array}{l}\text { King Abdullah City for Atomic } \\
\text { and Renewable Energy } \\
\text { (KACARE }\end{array}$ \\
\hline AHF 31107 & Mohammed Al Harbi & Saad AIQahtani & $\begin{array}{l}\text { King Abdullah City for Atomic } \\
\text { and Renewable Energy } \\
\text { (KACARE) }\end{array}$ \\
\hline PMO6 0807 & Joop Mes & Victor Cassella & Kipp \& Zonen USA, Inc. \\
\hline PMO6cc 0103 & Joop Mes & Victor Cassella & Kipp \& Zonen USA, Inc. \\
\hline AHF 31102 & Nai-Ju Hsueh & Kun-Wei Lin & $\begin{array}{l}\text { National Central University, } \\
\text { Taiwan }\end{array}$ \\
\hline AHF 23734 & Afshin Andreas & Mark Kutchenreiter & $\begin{array}{l}\text { National Renewable Energy } \\
\text { Laboratory (Cell and Module } \\
\text { Certification) }\end{array}$ \\
\hline
\end{tabular}




\begin{tabular}{|c|c|c|c|}
\hline $\begin{array}{l}\text { Serial Number } \\
\text { of Radiometer }\end{array}$ & Operator 1 & Operator 2 & Affiliation \\
\hline AHF 28968 & Afshin Andreas & Mark Kutchenreiter & $\begin{array}{l}\text { National Renewable } \\
\text { Energy Laboratory } \\
\text { (Metrology and SePA) }\end{array}$ \\
\hline AHF 29219 & Afshin Andreas & Mark Kutchenreiter & $\begin{array}{l}\text { National Renewable } \\
\text { Energy Laboratory } \\
\text { (Metrology and SePA) }\end{array}$ \\
\hline AHF 29220 & Afshin Andreas & Mark Kutchenreiter & $\begin{array}{l}\text { National Renewable } \\
\text { Energy Laboratory } \\
\text { (Metrology and SePA) }\end{array}$ \\
\hline AHF 30713 & Afshin Andreas & Mark Kutchenreiter & $\begin{array}{l}\text { National Renewable } \\
\text { Energy Laboratory } \\
\text { (Metrology and SePA) }\end{array}$ \\
\hline $\begin{array}{l}\text { AHF 31104- } \\
\text { Window }\end{array}$ & Afshin Andreas & Mark Kutchenreiter & $\begin{array}{l}\text { National Renewable } \\
\text { Energy Laboratory } \\
\text { (Metrology and SePA) }\end{array}$ \\
\hline AHF 32452AWX & Afshin Andreas & Mark Kutchenreiter & $\begin{array}{l}\text { National Renewable } \\
\text { Energy Laboratory } \\
\text { (Metrology and SePA) }\end{array}$ \\
\hline TMI 68018 & Afshin Andreas & Mark Kutchenreiter & $\begin{array}{l}\text { National Renewable } \\
\text { Energy Laboratory } \\
\text { (Metrology and SePA) }\end{array}$ \\
\hline AHF 28553 & Emiel Hall & Jim Wendell & NOAA/ESRL/GMD \\
\hline AHF 31114AWX & Emiel Hall & Jim Wendell & NOAA/ESRL/GMD \\
\hline AHF 31116AWX & Emiel Hall & Jim Wendell & NOAA/ESRL/GMD \\
\hline AHF 32448AWX & Emiel Hall & Jim Wendell & NOAA/ESRL/GMD \\
\hline AHF 32455 & Wolfgang Finsterle & $\mathrm{n} / \mathrm{a}$ & PMOD/WRC \\
\hline PMO6 0401 & Wolfgang Finsterle & $\mathrm{n} / \mathrm{a}$ & PMOD/WRC \\
\hline PMO6cc 0803 & Wolfgang Finsterle & $\mathrm{n} / \mathrm{a}$ & PMOD/WRC \\
\hline AHF 31108 & Bill Boyson & Charles Robinson & $\begin{array}{l}\text { Sandia National Laboratories } \\
\text { (Photovoltaic Systems } \\
\text { Evaluation Laboratory) }\end{array}$ \\
\hline TMI 67603 & Bill Boyson & Charles Robinson & $\begin{array}{l}\text { Sandia National Laboratories } \\
\text { (Photovoltaic Systems } \\
\text { Evaluation Laboratory) }\end{array}$ \\
\hline AHF 31041 & Fred Denn & $\mathrm{n} / \mathrm{a}$ & $\begin{array}{l}\text { Science Systems and } \\
\text { Applications, Inc. }\end{array}$ \\
\hline AHF 31105 & Fred Denn & $\mathrm{n} / \mathrm{a}$ & $\begin{array}{l}\text { Science Systems and } \\
\text { Applications, Inc. }\end{array}$ \\
\hline AHF 34926AWX & Josh Peterson & $\mathrm{n} / \mathrm{a}$ & $\begin{array}{l}\text { University of Oregon Solar } \\
\text { Radiation Monitoring } \\
\text { Laboratory }\end{array}$ \\
\hline
\end{tabular}




\section{Appendix B. Ancillary Data Summaries}

The measurement performance of an ACR can be affected by several environmental parameters.

Potentially relevant meteorological data collected during the NPC are presented in this appendix.

The Baseline Measurement System has been in continuous operation at the SRRL since 1981.

Baseline Measurement System data are recorded as one-minute averages of three-second samples for each instrument. ${ }^{6}$ Time-series plots and other graphical presentations of these data acquired during the NPC-2019 measurements are presented here.

${ }^{6}$ Additional information about the SRRL and the Baseline Measurement System can be found on the Measurement and Instrumentation Data Center at http://www.nrel.gov/midc/srrl bms/. 
Reference Irradiance $\left[\mathrm{W} / \mathrm{m}^{2}\right]$

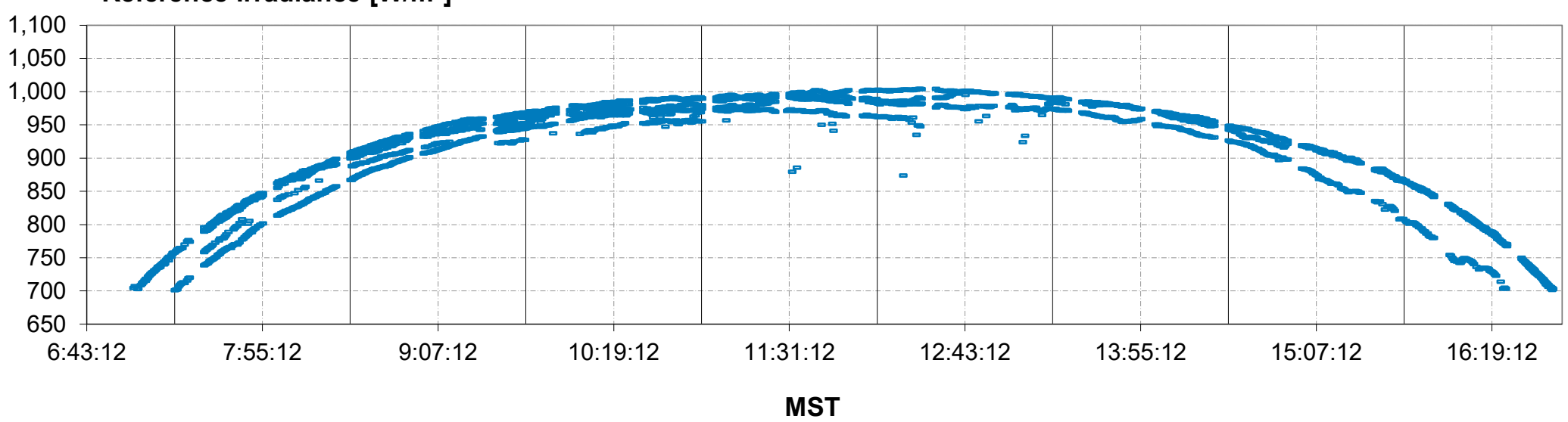

Figure B-1. Reference Irradiance (W/m2)

Est. Broadband Turbidity

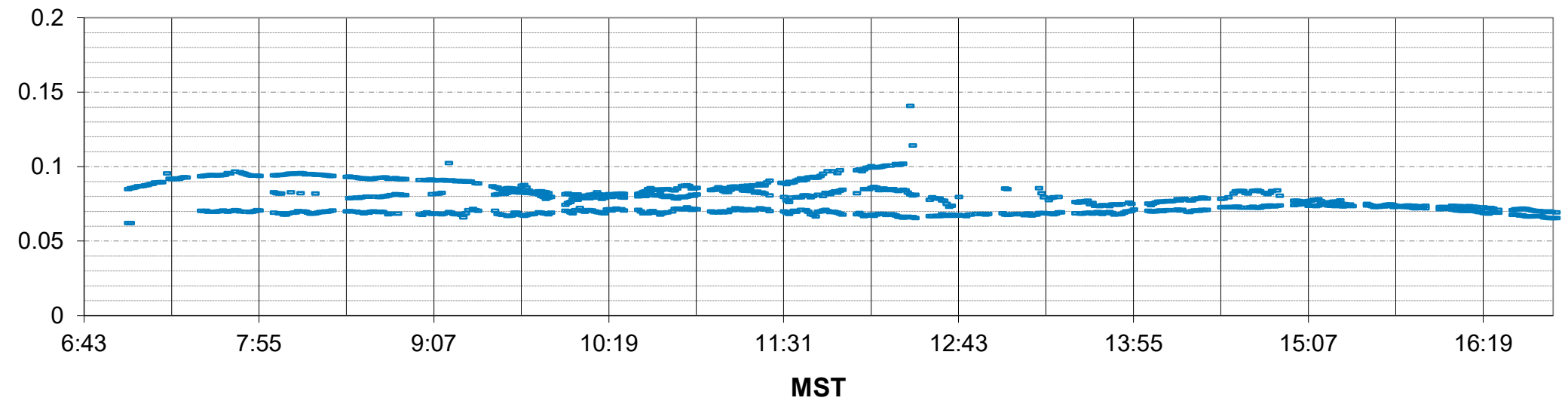

Figure B-2. Estimated broadband turbidity 


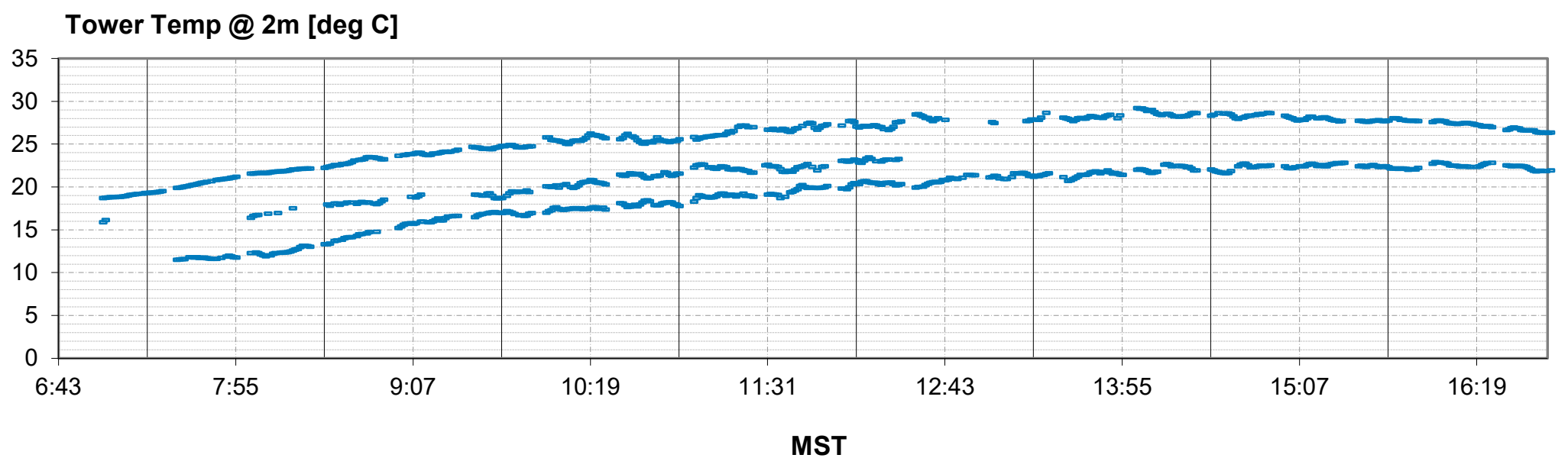

Figure B-3. Tower temperature at $2 \mathrm{~m}$ (deg. C)

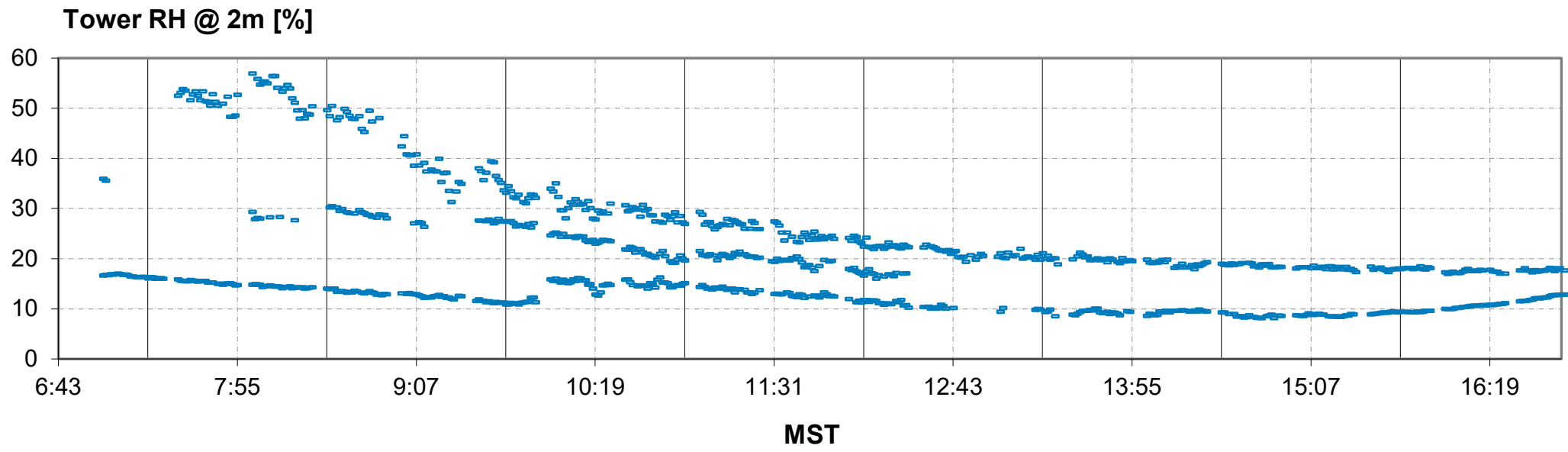

Figure B-4. Tower relative humidity at $2 \mathrm{~m}(\%)$ 


\section{Avg Wind Speed @ 2m [m/s]}

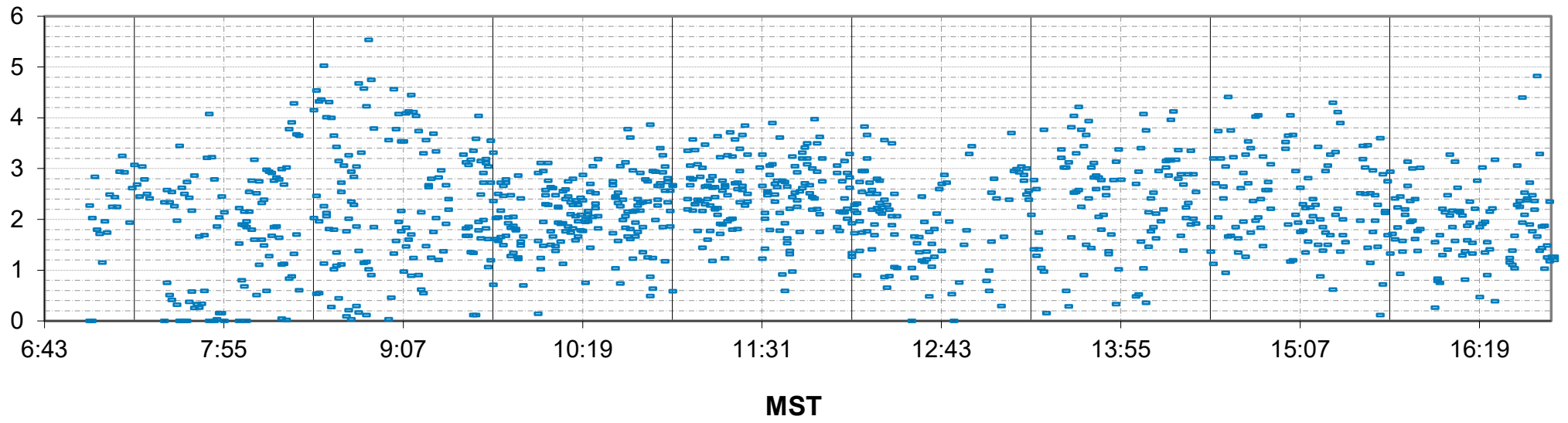

Figure B-5. Average wind speed at $2 \mathrm{~m}(\mathrm{~m} / \mathrm{s})$

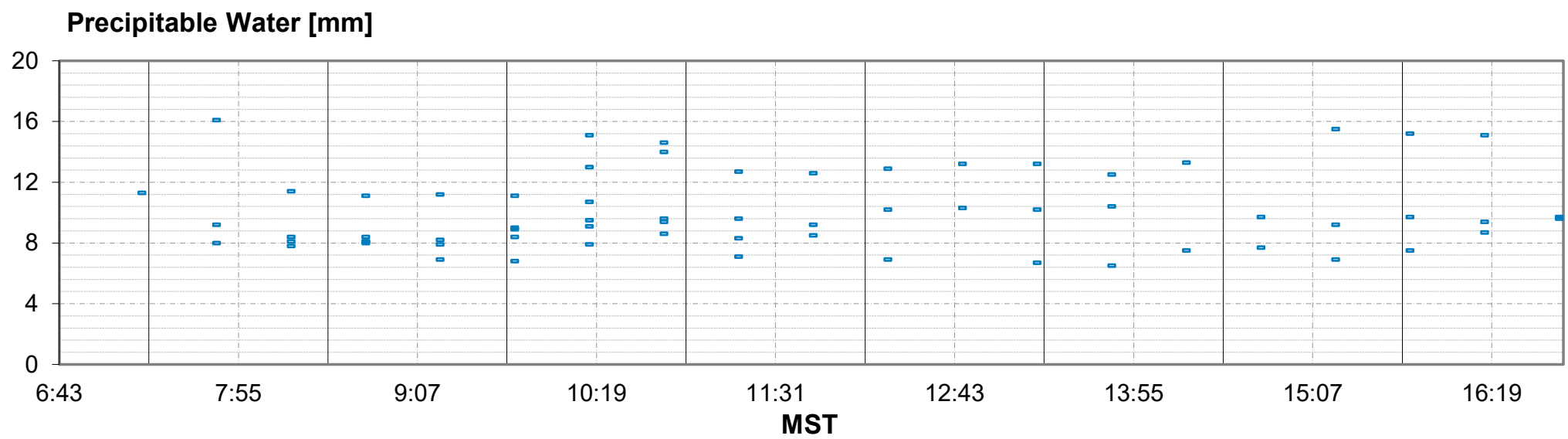

Figure B-6. Precipitable water (mm) 


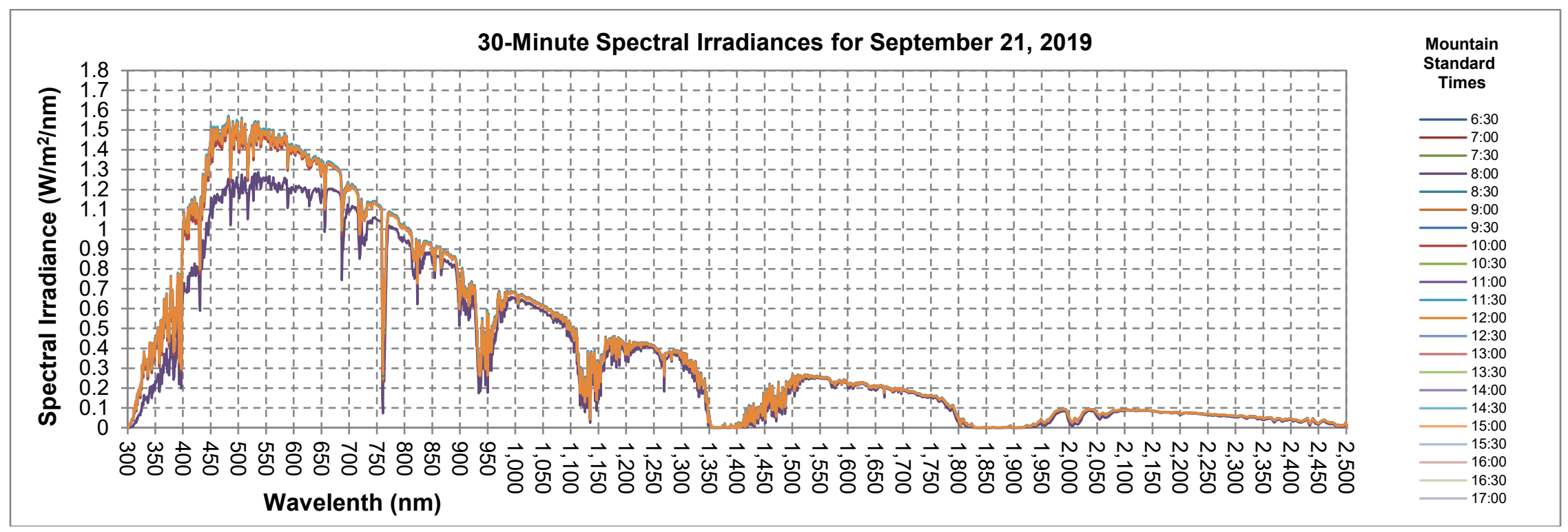

Figure B-7. 30-minute spectral irradiances for September 21, 2019

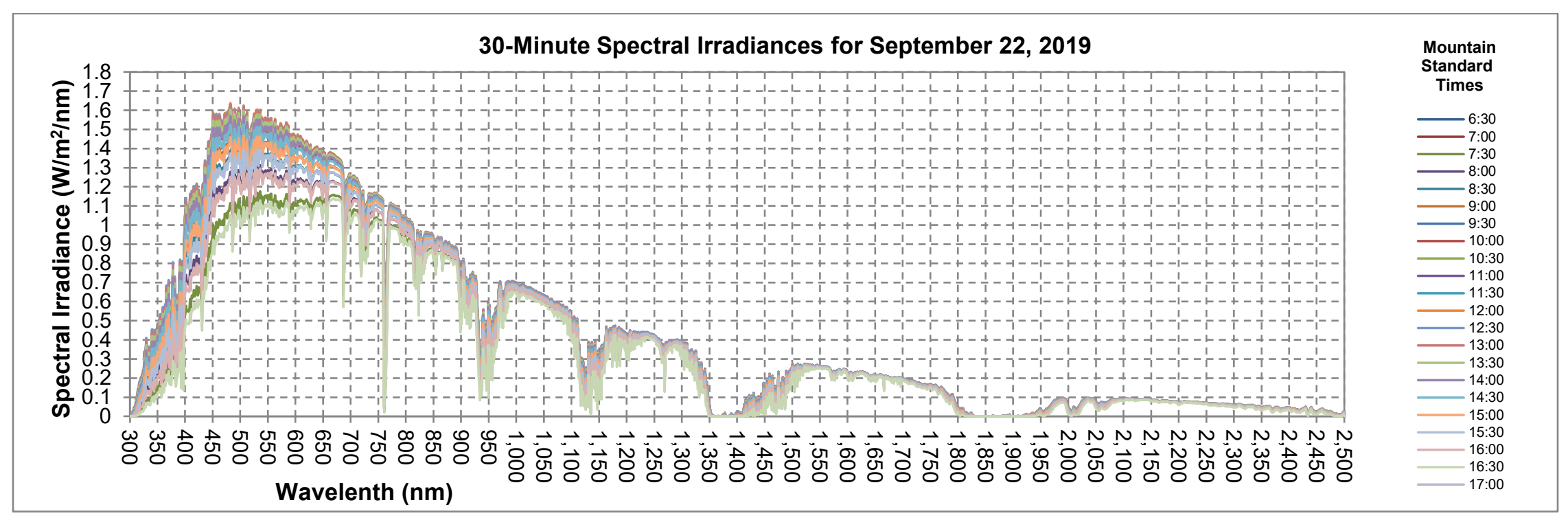

Figure B-8. 30-minute spectral irradiances for September 22, 2019 


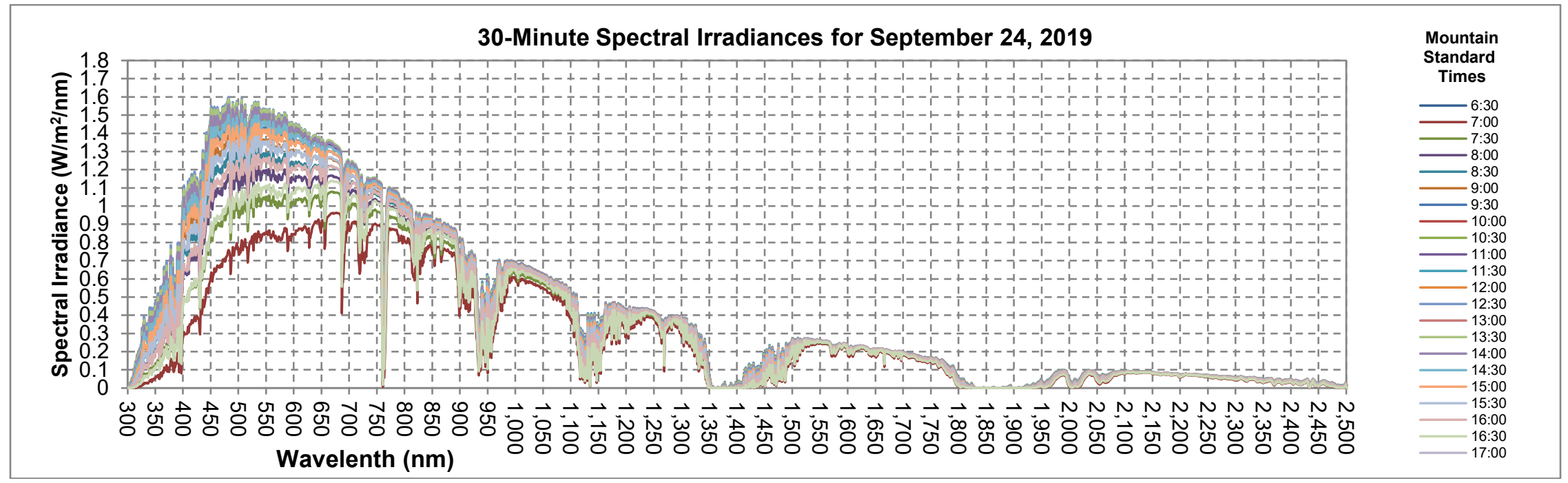

Figure B-9. 30-minute spectral irradiances for September 24, 2019

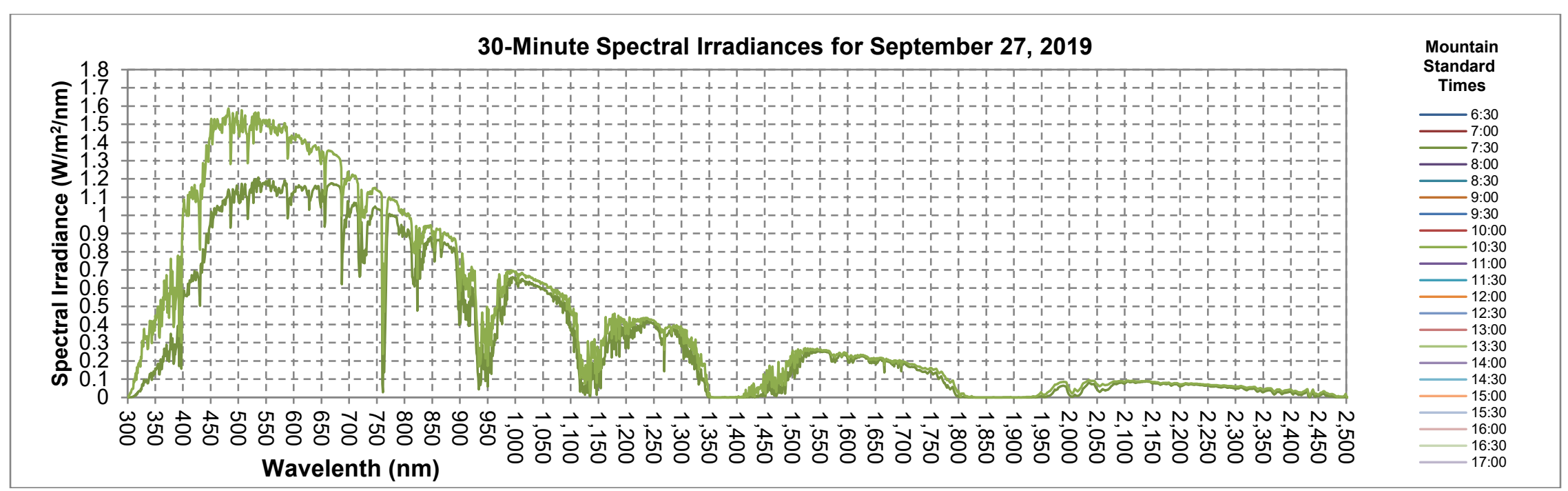

Figure B-10. 30-minute spectral irradiances for September 27, 2019 


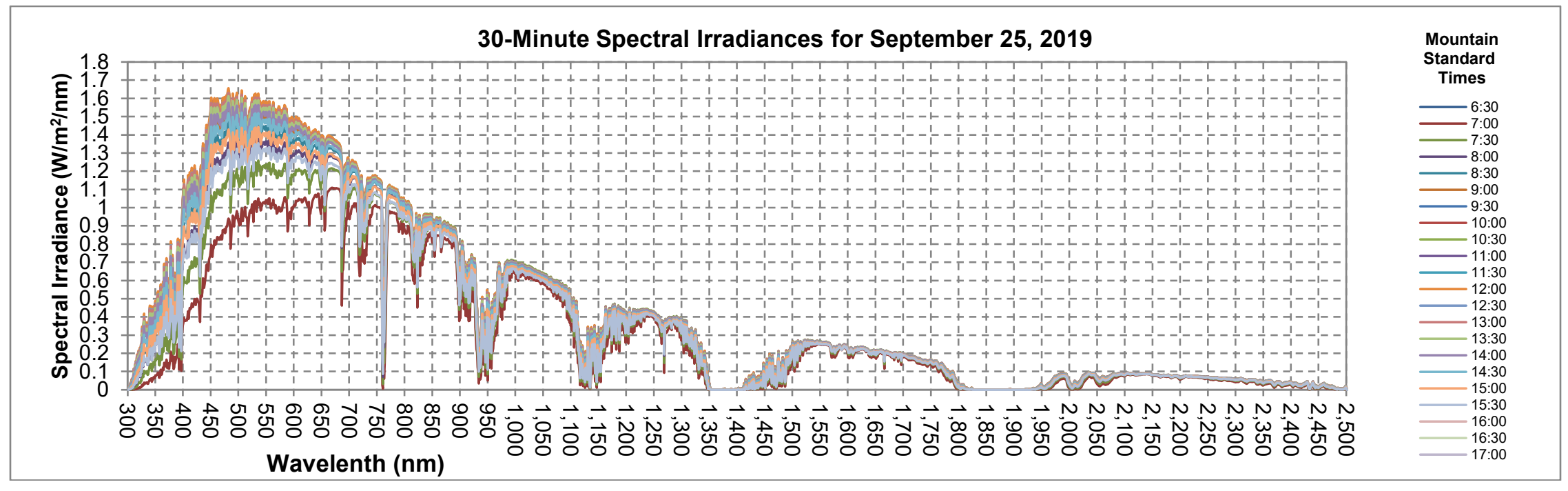

Figure B-11. 30-minute spectral irradiances for September 25, 2019

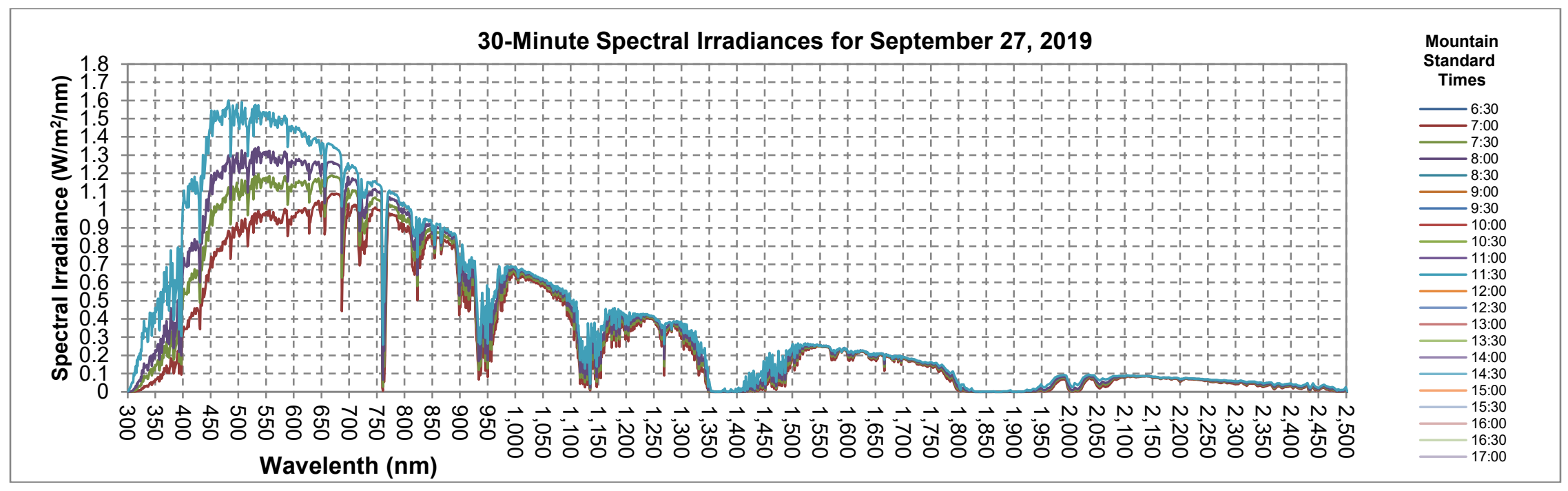

Figure B-12. 30-Minute Spectral Irradiances for September 27, 2019 